\title{
Poly-phased fluid flow in the giant fossil pockmark of Beauvoisin, SE basin of France
}

\author{
Aurélien Gay ${ }^{1, a,}{ }^{*}$, Alexiane Favier ${ }^{1,2}$, Jean-Luc Potdevin ${ }^{3}$, Michel Lopez ${ }^{1}$, Delphine Bosch ${ }^{1}$, \\ Nicolas Tribovillard ${ }^{3}$, Sandra Ventalon ${ }^{3}$, Thibault Cavailhes ${ }^{4}$, Martin Neumaier ${ }^{5}$, Sidonie Revillon ${ }^{6}$, \\ Anna Travé ${ }^{7}$, Olivier Bruguier ${ }^{1}$, Doriane Delmas ${ }^{1}$ and Christophe Nevado ${ }^{1}$ \\ ${ }^{1}$ Géosciences Montpellier, Université de Montpellier, CNRS, Université des Antilles, Montpellier, France \\ 2 Géoazur Nice, UMR CNRS 7329, Université Côte d'Azur, Observatoire de la Côte d'Azur, IRD, Géoazur, 06560 Valbonne, France \\ 3 Laboratoire d'Océanologie et Géosciences, UMR 8187, Université de Lille, ULCO, CNRS, 59000 Lille, France \\ ${ }^{4}$ Laboratoire EPOC - OASU, UMR 5805, Université de Bordeaux, CNRS, 33615 Pessac, France \\ ${ }^{5}$ Earth Science and Engineering, Imperial College London, Exhibition Road, London SW7 2AZ, UK \\ 6 SEDISOR/UMR CNRS 6538 LGO, Place Nicolas Copernic, 29280 Plouzané, France \\ ${ }^{7}$ Department of Mineralogy, Petrology and Applied Geology. Faculty of Earth Sciences, Barcelona University (UB), 08028 Barcelona, \\ Spain
}

Received: 13 January 2020 / Accepted: 19 August 2020

\begin{abstract}
The giant Jurassic-aged pockmark field of Beauvoisin developed in a 800 m wide depression for over 3.4 Ma during the Oxfordian; it formed below about $600 \mathrm{~m}$ water depth. It is composed of sub-sites organized in clusters and forming vertically stacked carbonate lenses encased in marls. This fine-scale study is focused on a detailed analysis of petrographical organization and geochemical signatures of crystals that grew up in early to late fractures of carbonate lenses, surrounding nodules, and tubes that fed them. The isotopic signature $(\mathrm{C}, \mathrm{O}$ and $\mathrm{Sr})$ shows that at least three different episodes of fluid migration participated to the mineralization processes. Most of the carbonates precipitated when biogenic seepage was active in the shallow subsurface during the Oxfordian. The second phase occurred relatively soon after burial during early Cretaceous and thermogenic fluids came probably from underlying Pliensbachian, Late Toarcian or Bajocian levels. The third phase is a bitumen-rich fluid probably related to these levels reaching the oil window during Mio-Pliocene. The fluids migrated through faults induced by the emplacement of Triassicsalt diapir of Propiac during the Late Jurassic and that remained polyphased drain structures over time.
\end{abstract}

Keywords: focused fluid flow / basin geology / pockmark / Beauvoisin / Tethyan margin / Oxfordian

Résumé - Migration poly-phasée de fluides dans le pockmark géant fossile de Beauvoisin, bassin du SE de la France. Le pockmark géant de Beauvoisin s'est développé dans une dépression de $800 \mathrm{~m}$ de diamètre pendant plus de 3,4 Ma à l'Oxfordien. Il est composé de sous-sites formant des lentilles carbonatées empilées verticalement et inter-stratifiées avec des marnes. Cette étude est basée sur une analyse détaillée de l'organisation pétrographique et des signatures géochimiques des cristaux qui se sont développés dans les fractures précoces à tardives des lentilles de carbonate, des nodules environnants et des tubes qui les alimentaient. La signature isotopique $(\mathrm{C}, \mathrm{O}$ et $\mathrm{Sr})$ montre qu'au moins trois épisodes différents de migration de fluides ont participé aux processus de minéralisation. La plupart des carbonates ont précipité grâce aux apports de fluides biogéniques provenant des marnes sous-jacentes pendant l'Oxfordien. La deuxième phase s'est produite relativement peu de temps après l'enfouissement au début du Crétacé et ce sont des fluides thermogéniques provenant des niveaux plus profonds du Pliensbachien, du Toarcien supérieur ou du Bajocien qui l'ont traversé, sans savoir si ceux-ci ont atteint le paléo-fond de mer. La troisième phase est un fluide riche en bitume probablement lié à ces mêmes niveaux atteignant la fenêtre à

\footnotetext{
*Corresponding author: aurelien.gay@umontpellier.fr

a Present address: Géosciences Montpellier, Université de Montpel-

lier, Case 060, Place Eugène Bataillon, 34095 Montpellier cedex 5,

France
} 
huile pendant le Mio-Pliocène. Les fluides ont migré par des failles induites par la mise en place du diapir de sel du Trias de Propiac, mais ces conduits initiaux restent ouverts et sont donc réutilisés par des fluides plus tardifs liés à l'enfouissement de cette structure au court du temps.

Mots clés : migration focalisée de fluides / géologie de bassin / pockmark / Beauvoisin / marge Téthys

\section{Introduction}

At seep sites, sulfide and methane release results in authigenic carbonate precipitation commonly forming lenses encased in surrounding limestones or marlstones (e.g., Campbell et al., 2002). Seeping fluids sustain chemosynthetic bacteria and organisms at the seafloor, which have been recognized both in modern and ancient seep sites (Clari et al., 1994; Campbell and Bottjer, 1995b; Campbell, 2006; Kiel and Little, 2006; Gay et al., 2006; Amano et al., 2010; Kiel, 2010; Teichert and van de Schootbrugge, 2013; Vrijenhoeck, 2013). The fluid seeps are all related to an underlying focused fluid flow system connecting a reservoir at depth through a network of preferential pathways (Bohrmann et al., 1998; Aloisi et al., 2000; Aloisi et al., 2002; Agirrezabala et al., 2013). Depending on the type of reservoir and/or trap (i.e., turbiditic channels, salt diapirs, anticline structures, glaciomarine tills), the nature (marine, lacustrine) and depth of the source rock, and the residence time in the sedimentary column, the fluids can have contrasting signatures once they reach the seafloor (Gay et al., 2007). It also means that a carbonate body, such as a carbonate lens or a fluid pipe, can record several generations of fluids during burial. For example, this is the case in the Mariana forearc where calcite and aragonite precipitated at different stages during the formation of a chimney (Tran et al., 2014).

The giant fossil pockmark of Beauvoisin (Drôme department, Haute-Provence area, France) is one of the few examples worldwide being equivalent to Cenozoic chemosymbioticrelated fossil sites (Campbell and Bottjer, 1995a). It was first interpreted as a hydrothermal vent (Rolin, 1987; Gaillard et al., 1996) and then reinterpreted as a cold seep site (Peckmann et al., 1999; Kiel, 2013). It is now considered as a long-lasting (3.44 Ma) pockmark in the vicinity of Triassic salt diapirs, active during the Oxfordian (Tribovillard et al., 2013; Gay et al., 2019). The carbonate constructions have been also termed "pseudo-bioherms" by the pioneering studies of authors from the University of Lyon (France; e.g., Artru, 1972; Bourseau, 1977; Gaillard et al., 1985).

The isotopic signature of all minerals found in carbonate lenses and masses, nodules and tubes will provide information on the conditions of formation and the origin of fluids. In particular, the Strontium Isotope Stratigraphy (SIS) methodology (McArthur et al., 2012) was recently applied to fossil seep-deposits providing reliable formation ages (Ge and Jiang, 2013; Kiel et al., 2014; Kiel and Hansen, 2015). In this study, the mineralogical assemblages were investigated in details to date the different phases of fluid flow in the giant fossil pockmark of Beauvoisin. The aim of this paper is to provide the fluid flow history during burial of a seep site, based on petrographical organization and geochemical signatures in carbonate lenses, marls, nodules and tubes.

\section{Geological setting}

The carbonate, lucinid and gastropod-bearing, constructions of Beauvoisin developed under synsedimentary conditions, during the Jurassic in the South-Eastern Basin of France (Artru, 1972; Bourseau, 1977; Rolin, 1987; Gaillard et al., 1996; Peckmann et al., 1999; Kiel, 2013; Tribovillard et al., 2013; Gay et al., 2019). Prior to the development of the pseudo-bioherms, from the Lias to the Dogger the shallowwater carbonate platform underwent frequent subaerial exposure or erosion indicating a stable margin with a slow rate of subsidence (Lemoine, 1985). During the Bathonian, the moderate subsidence of the southern platform was compensated by higher rates of sedimentation, but the environments remained shallow. The Bathonian sequence is characterized by marls alternating with thin mudstone layers. However, the northern platform was already deepening as indicated by cherts and organic-rich marls facies (Dardeau, 1988). A general subsidence affected the entire platform from the Callovian and during the Oxfordian leading to deep marl facies deposition alternating with pluri-cm to m-thick dolomudstones layers in the northern part, locally remobilized by submarine slides. The giant fossil pockmark of Beauvoisin developed during the Oxfordian on the slope of the Liguro-Tethyan Ocean where the subsidence was at a maximum, leading to the deposition of up to $2000-2500 \mathrm{~m}$ of dark-grey organic-rich marls called the "Terres Noires" Formation (Gaillard et al., 1985; Gaillard and Rolin, 1988; Caillaud, 2018). The Late Oxfordian is characterized by the so-called Argovian sequence composed of thick amber-colored dolomudstone layers alternating with light brown marls in a general thickening upward sequence. Within the giant pockmark of Beauvoisin the thickness of the Argovian sequence varies by a factor of 3 to 4 which could be due to syn-to-post depositional erosion or slump processes on slopes of the depression (Gay et al., 2019). Subsidence was mostly due to basement faults with kinematics controlled by salt withdrawal in the extensional domain of the margin (Mascle, 1988). The giant pockmark of Beauvoisin is bounded to the west by major salt-rooted faults, which facilitated growth of the salt diapir of Propiac composed of Triassic evaporites (Fig. 1). The faults and the correlative salt diapir movements were active during the deposition of the Terres Noires in the area of Beauvoisin and some other places in the South-eastern Basin (Artru, 1972; Debrand-Passard, 1984; Tribovillard et al., 1987).

\section{Methods and data}

The site of Beauvoisin is characterized by 19 fossil-rich carbonate lenses embedded in fine-grained marls (sub-sites A to T, see Fig. 2 for log stratigraphy). Since its first recognition in the 1970s (Artru, 1972; Bourseau, 1977; Gaillard et al., 

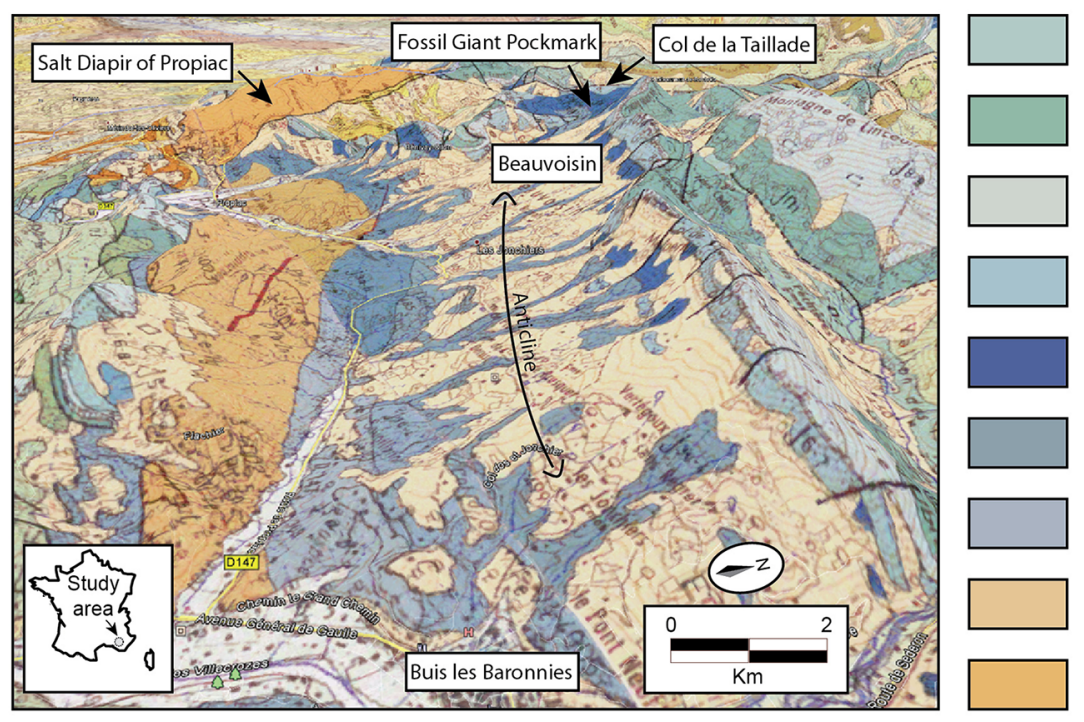

$\mathrm{n} 2$ Valanginian

Jn1 Berriasian

J8-9 - Upper Kimmeridgian

\& Tithonian

J6-7 - Upper Oxfordian \&

Lower Kimmeridgian

J5 - Middle Oxfordian

$\&$ Argovian sequence

J3c-4 - Upper Callovian

\& Lower Oxfordian

J3a-b - Lower \& Middle

Callovian

J2 - Bathonian

$\begin{array}{ll}\text { t-Trias } & \text { Faults } \\ \text { \&Veins }\end{array}$

Fig. 1. View to the west on the geological map of the anticline structure of Buis-les-Baronnies (BRGM, Geological maps 891, 892, 915 and 916). The study area is located near Beauvoisin where a fossil seep site has been identified in the "Terres Noires" Formation (Oxfordian) since the 1980s (Gaillard et al., 1985). It is now interpreted as a fossil giant pockmark (Gay et al., 2019), that developed in the vicinity of the Triassic salt diapir of Propiac.

1985; Rolin, 1987, Gaillard and Rolin, 1988; Rolin et al., 1990), erosion has exposed new sub-sites that have been recently reported in a precise stratigraphical $\log$ (Gay et al., 2019) following the initial nomenclature established 20 years ago by Rolin (1987). Some key layers, such as the few cmthick bentonite layers documented by Pellenard et al. (2003) or the R1 to R20 layers of the Argovian sequence (Fig. 2), are used as reference layers and correlated to the Tethyan sequences (Gradstein, 2012). This study is based on the analysis of the macroscopic and microscopic fabric of the carbonate lenses encased in the surrounding marls of the "Terres Noires" Formation. Twenty-four uncovered vertical $30 \mu \mathrm{m}$ thin-sections regarding the carbonate lenses were prepared to perform the petrographic study, prior to geochemical analyses.

Analyses of $\mathrm{C}$ and $\mathrm{O}$ isotopes were conducted at the University of Barcelona on calcites extracted from uncovered thin-sections using a micro-drill to determine the carbon and oxygen stable isotope ratio of the different cements using the standard technique of Craig and Gordon (1965) and Claypool et al. (1980). The $\mathrm{CO}_{2}$ was extracted from $60 \pm 10 \mu \mathrm{g}$ of powdered carbonate samples, which were reacted with $103 \%$ phosphoric acid for $2 \mathrm{~min}$ at $70^{\circ} \mathrm{C}$ for calcites. The $\mathrm{CO}_{2}$ was analyzed using an automated Kiel Carbonate Device attached to a Thermal Ionization Mass Spectrometer Thermo Electron (Finnigan) MAT-252. The results are precise to $\pm 0.02 \%$ for $\delta^{13} \mathrm{C}$ and $\pm 0.04 \%$ for $\delta^{18} \mathrm{O}$.

Strontium isotopic analyses were performed at University of Montpellier on calcites extracted from uncovered thinsections using a micro-drill. Samples were cleaned during three cycles, in alternating rinsing of alcohol and MilliQ high purity de-ionized water for half an hour in an ultrasonic bath. Once cleaned and dried in a laminar flow hood, the samples were weighed in pre-cleaned Teflon beakers. The samples were then dissolved in closed Teflon beakers with a mixture of concentrated HF $48 \%$ and $\mathrm{HCl} 12 \mathrm{~N}(0.5: 2)$ and put on a hot plate at $110^{\circ} \mathrm{C}$ during 24 hours. After evaporation to dryness, $\mathrm{HNO}_{3}$ was added to the residue and kept at $110^{\circ} \mathrm{C}$ for six hours before another evaporation step to dryness. Strontium isotopic compositions of representative samples were analyzed on unspiked samples. Chemical separation of $\mathrm{Sr}$ was done following two main steps. The first chemistry was done using the modified procedure of Richard et al. (1976) using a cationic exchange resin (Biorad AG50WX8). The objective was to concentrate only the alkaline earth elements and to remove the other elements from the matrix. The second chemistry was done using the Eichrom Sr-Spec ion-exchange resin in order to isolate $\mathrm{Sr}$ following a procedure modified from Pin et al. (1994). Total chemistry blanks were less than $20 \mathrm{pg}$ and thus negligible for this study. Strontium isotopes were measured by thermal ionization mass spectrometry using a Triton Finnigan Mat spectrometer at Labogis (University of Nîmes). The samples were alternatively run with international NBS 987 standards using measurement procedure wherein standards were run every six unknowns. The ${ }^{88} \mathrm{Sr}$ beam intensities for all standards and samples ranged from $10 \mathrm{~V}$ to $20 \mathrm{~V} .{ }^{87} \mathrm{Sr} /{ }^{86} \mathrm{Sr}$ isotopic ratios were internally corrected from the instrumental bias using a value of 0.1194 for the ${ }^{86} \mathrm{Sr} /{ }^{88} \mathrm{Sr}$ ratio. Then the corrected ratios were normalized to the NBS 987 standards that gave a mean value of 0.710249 with a reproducibility of $\pm 0.000006(2 \mathrm{~s}, n=5)$ during the course of this study. All ages are provided following the SIS (Strontium Isotope Stratigraphy) curve (McArthur et al., 2012) and the revised Jurassic strontium curve (Wierzbowski et al., 2017) as shown in the Figure 3.

The thin-sections were studied under optical microscopy, cathodoluminescence microscopy (CL), scanning electron microscopy (SEM) and Raman spectroscopy:

We used an Olympus BX 60 microscope, which allows polarized transmitted light and reflected light microscopic observation on the thin-sections. Conventional optical microscopy was supplemented by cathodoluminescence 

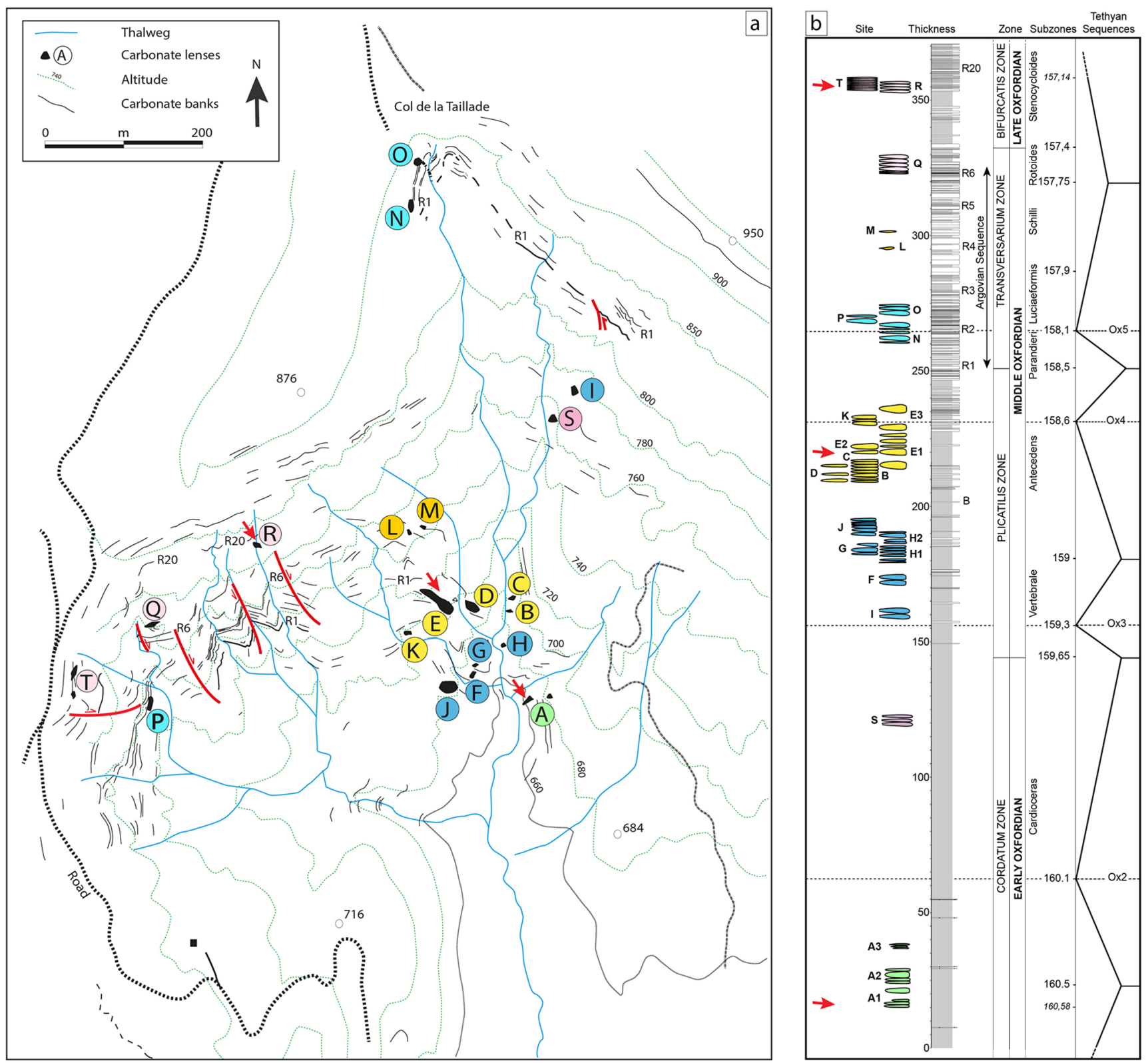

Fig. 2. Left: detailed topographic map of the Beauvoisin area (modified after Gaillard et al., 1985). Nineteen sub-sites have been reported, including two new sites, S and T, which were exposed due to weathering since their initial discovery (Gay et al., 2019). Right: $360 \mathrm{~m}$ thick composite log of the Oxfordian in the Beauvoisin area (Gay et al., 2019). The red arrows show the three studied sub-sites A1, E1 and R, that developed during Early, Middle and Late Oxfordian respectively.

imaging, using a CITL MK4 optical Cold Cathode Luminescence stage fitted on an Olympus BX41 microscope. The accelerating voltage was $8-12 \mathrm{kV}$ and the current of the electron gun was 200-300 $\mu \mathrm{A}$. The images were acquired with a Spot Flex color camera of Diagnostic Instrument using a Kodak scientific grade CCD sensor of 4 megapixel. This cooled-high resolution-low light camera allows to image carbonate cements using a rather short exposure time.

SEM observations and analyses were conducted using a FEI Quanta 200 Environmental Scanning Electron Microscope (ESEM) fitted with an X-ray Energy Dispersive System (EDS).
The tungsten electron source was at $20 \mathrm{kV}$. The spatial resolution of the EDS probe, a Roentec Single Drift Detector, is about $1 \mu \mathrm{m}^{3}$. Pictures were taken using the back-scattered electrons (BSE) mode. The ESEM was used under high vacuum conditions with carbon-coated thin-sections to obtain better accuracy on the chemical analyses of minerals using the EDS system.

A Raman spectrometer (JY Horiba, Labram HR800UV) has been used to identify the mineral phases on some polished thin-sections. This apparatus is equipped with an electronically cooled charge-coupled device (CCD) detector, using $532 \mathrm{~nm}$ 


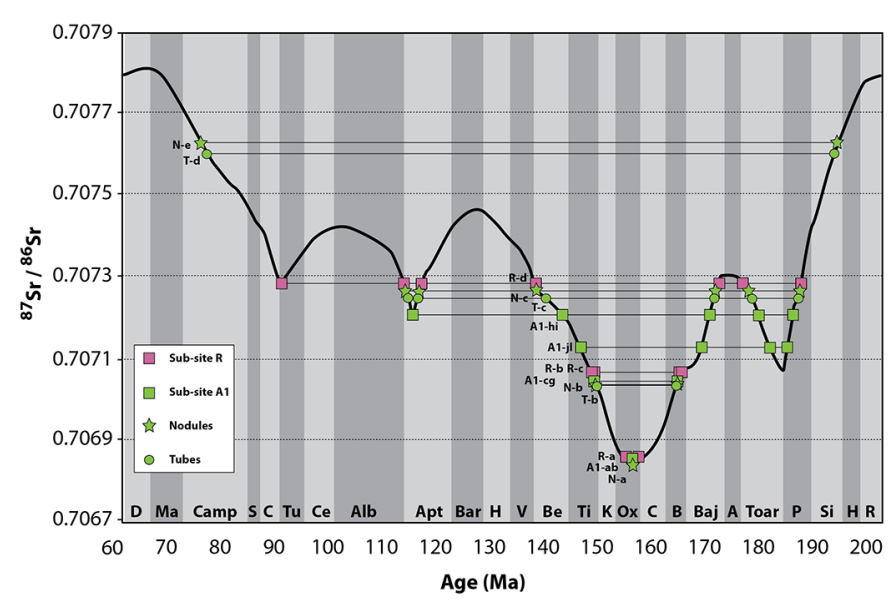

Fig. 3. ${ }^{87} \mathrm{Sr} /{ }^{86} \mathrm{Sr}$ ratios measured on all samples (Tubes T, Nodules $\mathrm{N}$, sub-site A1 and sub-site R) were reported on the strontium isotopic curve (black curve of the figure) from McArthur et al. (2012) and the Middle-Upper Jurassic revised version of Wierzbowski et al. (2017). At the bottom the abbreviated geological periods are indicated from the Rhetian ( $\mathrm{R}$ on the right) to the Danian (D on the left).

laser excitation. Spectra were obtained using $100 \times$ magnification objective. The acquisition time ranges between 20 and $60 \mathrm{~s}$ and the number of iteration ranges between 1 and 3 for each analysis.

\section{Carbonate lenses architecture, example of the seep sub-site E1}

The giant pockmark of Beauvoisin is characterized by 19 sub-sites (A to T) forming local unconformities in the Terres Noires Formation (see Gay et al., 2019 and references therein). Each sub-site is composed of sub-vertically stacked 0.5 to $2 \mathrm{~m}$ thick carbonate lenses surrounded by $\mathrm{cm}$ to $\mathrm{dm}$ nodules in a 100-120 m wide smooth depression 4 to $6 \mathrm{~m}$ deeper than the seabed (Gay et al., 2019). The nodules are encased in the carbonate lenses in the center of the depression whereas their size varies depending on the distance from the carbonate lenses. The sub-sites are organized in clusters grouped together in the same stratigraphic interval and the same geographic zone within the pockmark. The coalescence of all clusters (and their associated depressions) leads to the formation of a $800 \mathrm{~m}$ wide general depression interpreted as a giant fossil pockmark (Gay et al., 2019).

In this context, the sub-site E1 is very well exposed allowing a pseudo-3D view of the internal organization of an individual carbonate lens (see Fig. 2a for location). It developed during the Middle Oxfordian and it belongs to the Plicatilis zone and Antecedens sub-zone (Fig. 2b), as previously defined by Gaillard et al. (1985) and Rolin (1987), referring to the Tethyan sequences and age model from Gradstein (2012). The sub-site E1 forms a $4 \mathrm{~m}$ high edifice composed of sub-vertically stacked, $2-10 \mathrm{~m}$ wide and 0.5 to $1.5 \mathrm{~m}$ thick, massive carbonate lenses that are in contact (i.e., the top of an underlying lens is in sharp contact with the bottom of the overlying lens) or interbedded with nodule-rich marls (Fig. 4a). The carbonate lenses are composed of a micritic matrix rich in $\mathrm{Mg}$-calcite, aragonite and dolomite, which are the common authigenic minerals of cold-seep sites (Roberts et al., 1993). Within an individual carbonate lens the nodule size is generally 1 to $2 \mathrm{~cm}$ at the base, decreasing to $\mathrm{mm}$ at the top whereas they can reach $15 \mathrm{~cm}$ in diameter in surrounding marls. Bitumen is frequent within the nodules encased in marls and not in nodules encased in carbonate lenses. As for sub-site F (see Gay et al., 2019 for details), the carbonate lenses are affected by breccia composed of $\mathrm{mm}$ to $\mathrm{dm}$ sub-angular clasts. The top of the upper lens of many sub-sites is affected by pervasive corrosion forming an irregular pluri-cm thick MnFe-rich crust with pyrite inclusions. Remnant pyrite-encrusted micrite nodules can be found in overlying marls for a few $\mathrm{cm}$ to a few dm above the oxidized crust.

The carbonate lenses are dominated by endofauna, such as lucinid bivalves Beauvoisina carinata (Gaillard et al., 1985; Rolin et al., 1990; Gaillard et al., 1992), where they can form dense groups with some specimens reaching $18 \mathrm{~cm}$ in diameter (Rolin, 1987). Some other species have been identified in various abundance, such as gastropods, ammonites, crustacean exoskeletons, fragments and coprolites, fecal pellets, fish teeth, sponge spicules, echinoids, holothuroids, crinoids, benthic foraminifers, planktonic foraminifers, ostracods, radiolarians and dinoflagellates (Gaillard et al., 1985; Gaillard and Rolin, 1988; Rolin et al., 1990; Gaillard et al., 1992; SenowbariDaryan et al., 2007; Kiel, 2010; Gaillard et al., 2011; Kiel, 2013). This biota is common in the Jurassic seafloor in the area suggesting a bathyal environment estimated around $600 \mathrm{~m}$ water depth (Tribovillard et al., 2013).

Most of the carbonate lenses are rich in macro-fauna, mainly lucinids, with a few exceptions. This is particularly the case towards the top of the sub-site E1. The carbonate lenses are lenticular in shape, meaning that they are laterally passing to the marls. On a vertical section (left view or front view on Fig. 4b) the thickest part of an overlying carbonate lens is systematically located where the underlying carbonate lens is thinning or absent (Fig. 4b). This suggests that the sub-site E1 is formed by the progressive lateral shift of the carbonate lenses in any direction through time with respect to the general stratigraphy $\left(\mathrm{S}_{0}\right)$.

\section{Main facies in a seep sub-site (R)}

The sub-site R (see Fig. 2a for location) developed during the Late Oxfordian and belongs to the Bifurcatis zone and Stenocycloides sub-zone (Fig. 2b) referring to the Tethysian sequences and age model from Gradstein (2012). As for subsite E1, the sub-site $\mathrm{R}$ is composed of vertically stacked carbonate masses that are lenticular in shape (Fig. 5). The front view (Fig. 5a1-a2) shows that the thickness of the carbonate lenses is laterally compensated, meaning that the sub-site $\mathrm{R}$ is formed by the successive lateral shift of carbonate lenses through time. On the left view the irregular bases and tops of some carbonate lenses laterally pass to more massive carbonate beds (Fig. 5c1-c2) concordant to the general stratigraphy $\left(\mathrm{S}_{0}\right)$. These lenses are generally thicker than the other carbonates lenses, suggesting more favorable environmental conditions linked to better conditions of carbonate precipitation and/or preservation.

The top of the uppermost lens is affected by pervasive corrosion creating vugs and irregular surfaces. The corrosion 


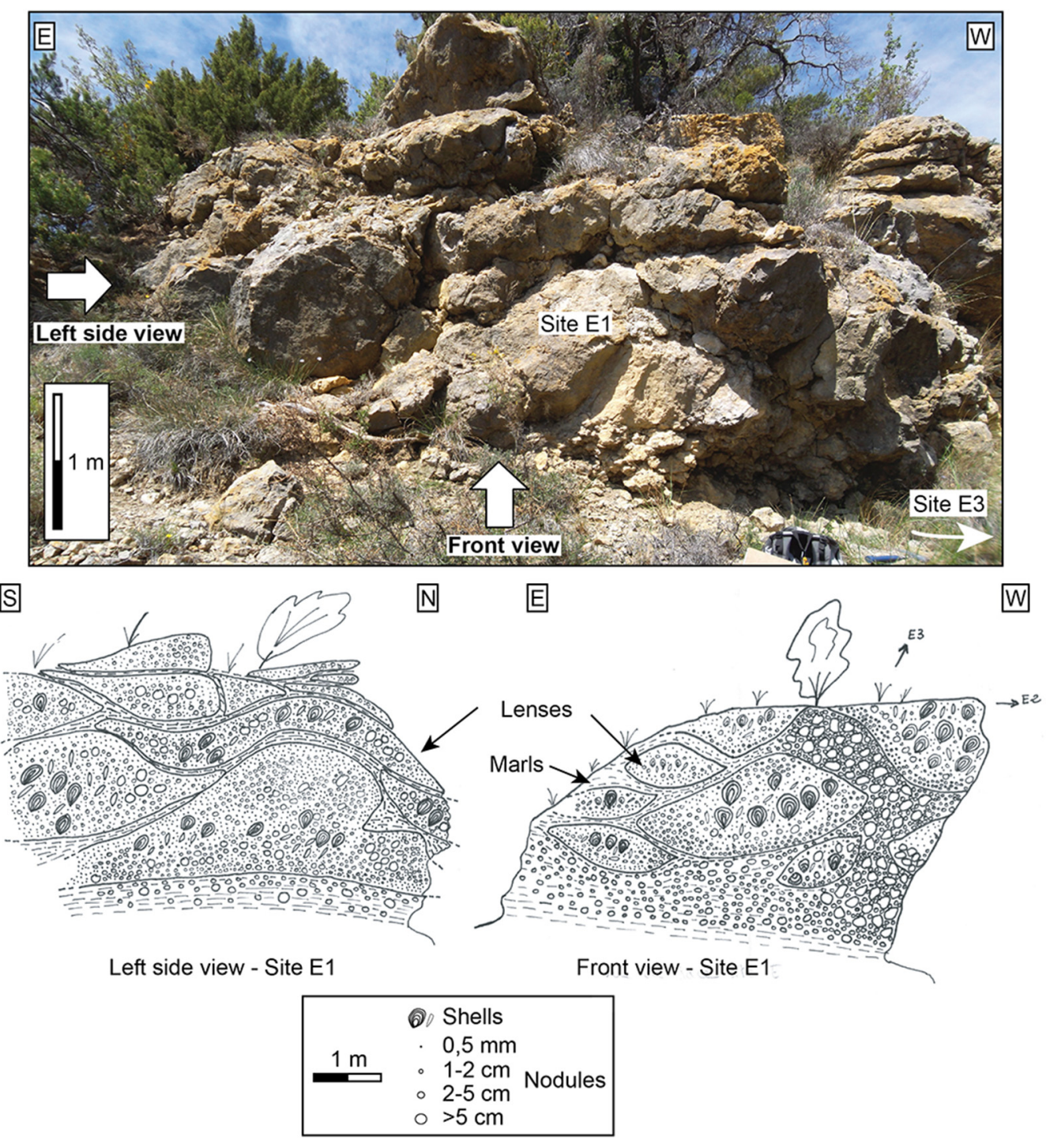

Fig. 4. Up: photograph to the south of the sub-site E1 (see Fig. 2 for location) located in the Plicatilis zone (Middle Oxfordian). Down: interpreted drawings of the front view and the left side view showing carbonate lenses, lenticular in shape, interbedded with nodules-rich marls. On a vertical section, the thickest part of an overlying carbonate lens is systematically located where the underlying carbonate lens is thinning; this staggered arrangement suggests a progressive lateral shift of the carbonate lenses in any direction through time with respect to the general stratigraphy $\left(\mathrm{S}_{0}\right)$.

surface is associated to a thick and massive $\mathrm{Mn}$-Fe-rich carbonate crust (Fig. 6a and see Fig. 5c1 for location). This oxidized crust is in close association with numerous pyrite-rich nodules and vertical tubes, a few $\mathrm{mm}$ to $1 \mathrm{~cm}$ in diameter or height encased in the overlying marls (Fig. $6 \mathrm{~b}$ and see Fig. $5 \mathrm{c} 1$ for location). The latter were never found elsewhere (i.e., laterally at the same stratigraphic level), suggesting a genetic relationship with the sub-site $\mathrm{R}$.

Lucinid bivalves are the most prominent biota associated with the carbonate lenses of the sub-site $\mathrm{R}$ where they can locally form dense aggregates (Fig. 7a and see Fig. 4a1 for location). The shells can reach a diameter of 5 to $8 \mathrm{~cm}$, suggesting that they fed on relative abundant food and nutrients (Rolin, 1987; Gay, 2002; Gay et al., 2019), but probably less abundant than on sub-site E1 where shells are larger. A thin-section realized in a lucinid-rich carbonate lens displays pluri-cm clasts made of yellowish or light-brown, microbial, micritic matrix, separated by veins (Fig. 7b, c). The micritic matrix is composed of detrital grains (mainly quartz) and pyrite framboids. it also contains some well-preserved shells and numerous $\mathrm{mm}$ to pluri-mm dark nodules coating body fossils, such as ammonites, bivalves, spicules and any biodetritus or burrows (Gaillard et al., 1985; Rolin, 1987). Preserved shells and more densely packed nodules are located in the vicinity of conduits and veins (Fig. $7 \mathrm{~b}, \mathrm{c}$ ). The $\delta^{13} \mathrm{C}$ values can reach a minimum of $-25 \%$ V-PDB on average in 

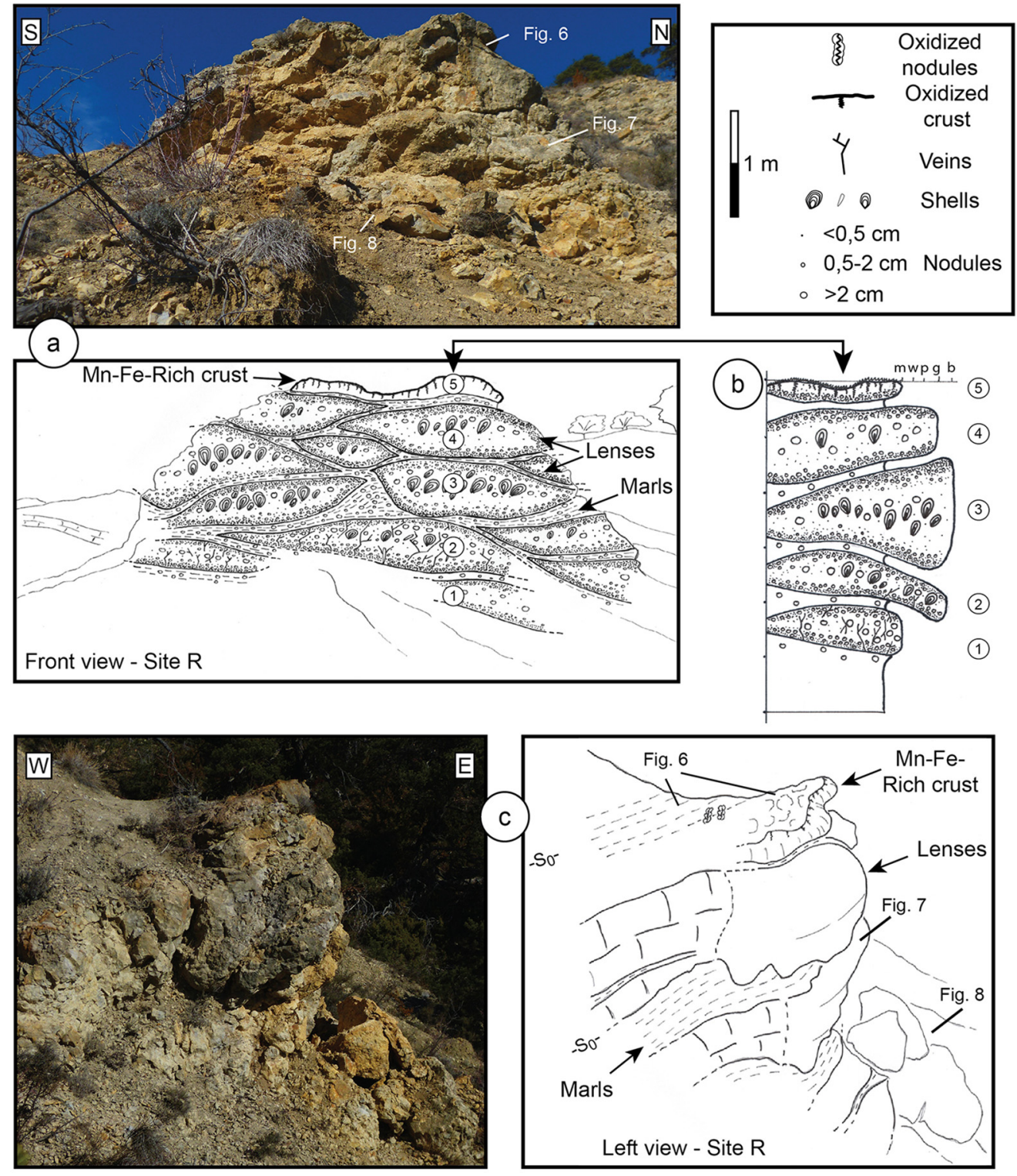

Fig. 5. (a) Photograph to the west of the sub-site R located in the Bifurcatis zone (Late Oxfordian) and its interpreted drawing (see Fig. 2 for location). (b) Stratigraphic log showing sub-vertically stacked carbonate lenses interbedded with nodules-rich marls. The basal carbonate lens displays a brecciated facies dominated by veins yielding mineralizations and displaying a jigsaw-like structure. (c) Detailed photograph to the north showing the left view of the sub-site R. The carbonate lenses are laterally passing to micritic beds of carbonates. The top of the edifice is characterized by a dm-thich oxidized crust (see Fig. 6)

encased nodules (Peckmann et al., 1999), similar to the micritic matrix (Gay et al., 2019), whereas the $\delta^{13} \mathrm{C}$ values in shells are $+5 \%$ V-PDB on average (Peckmann et al., 1999).

The basal lenses are systematically brecciated, forming various-sized, cemented, sub-angular clasts in a jigsaw-like structure, as for most of the other sub-sites in the area. However, they lack from macro-fauna, such as lucinids, or the shells are smaller than in overlying lenses. The brecciated facies is a matrix-supported cemented macrSo-breccia made up of $\mathrm{cm}$ to dm-size sub-angular micritic to microsparitic clasts within the carbonate matrix associated with abundant pyrite framboids (Fig. 8a, see Fig. 5a1 for sampling location). Thinsection observations in the basal lens shows that the brecciated facies is in close association with very sinuous mineralized veins filled by several generations of carbonate cements (Fig. $8 b)$. In plane polarized light, a first generation of iron-rich micro-sparitic calcite (C1) is generally found in shell fragments or thin veins (Fig. 8c). This first generation of $\mathrm{C} 1$ is then followed by at least three generations of high $\mathrm{Mg}$ calcite or aragonite $(\mathrm{C} 2-\mathrm{C} 4)$ filling the veins (Fig. 8c).

The sample R-a was taken in a shell fragment containing the first generation of micro-sparitic calcite $\mathrm{C} 1$ (Fig. 8c). The isotopic analyses display a $\delta^{13} \mathrm{C}$ value of $-14.82 \%$ V-PDB and a $\delta^{18} \mathrm{O}$ value of $-4.69 \%$ V-PDB (Tab. 1). The measured ${ }^{87} \mathrm{Sr}{ }^{86} \mathrm{Sr}$ ratio of $0.706855 \pm 10.10^{-6}$ is consistent with an Early Oxfordian or Late Oxfordian age (Fig. 3).

Two samples (R-b and R-c) were taken at two different locations, in the middle of a thick vein hosting the following 


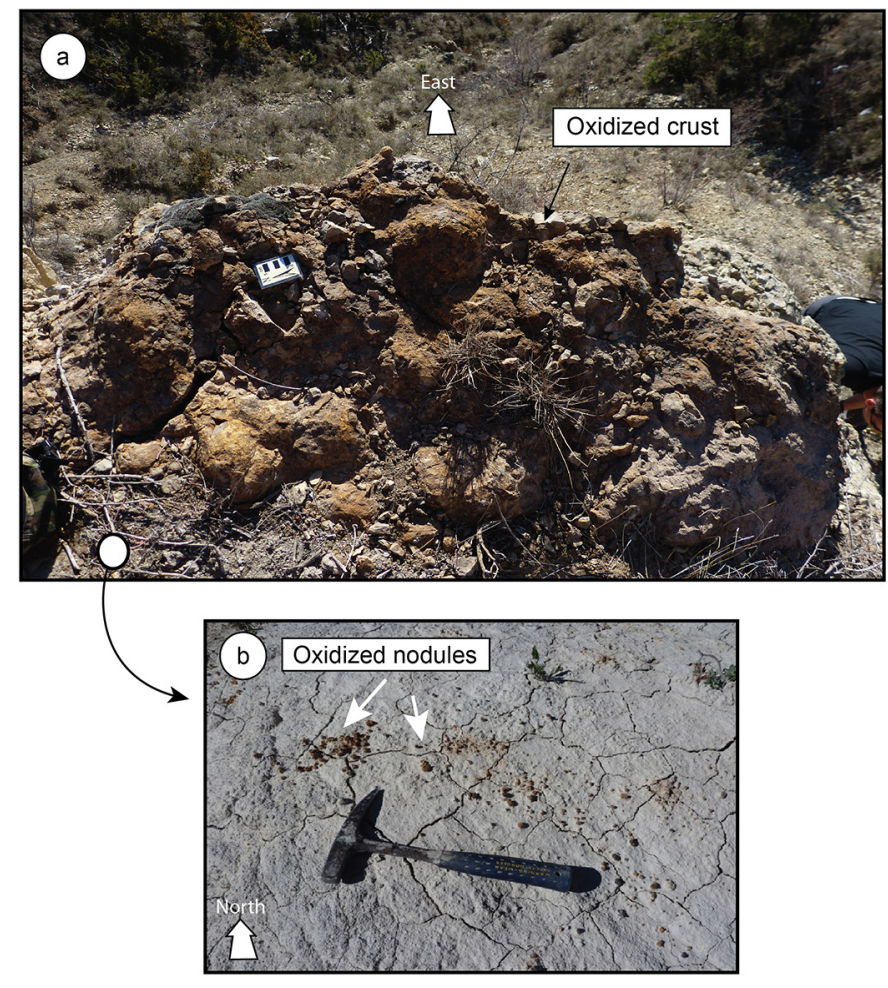

Fig. 6. (a) Detailed photograph to the East of the dm-thick oxidized crust showing pervasive corrosion on top of the sub-site R (see Fig. 5 for location). (b) Detailed photograph showing pyrite-encrusted micrite nodules overlying marls for a few $\mathrm{cm}$ to a few $\mathrm{dm}$ above the oxidized crust.

generation of a brown drusy calcite $\mathrm{C} 2$ (Fig. 8c). The calcite $\mathrm{C} 2$ is in contact with the micritic matrix and is usually coating clasts. The isotopic analyses $\left(\delta^{13} \mathrm{C}, \delta^{18} \mathrm{O}\right.$ and $\left.{ }^{87} \mathrm{Sr} /{ }^{86} \mathrm{Sr}\right)$ are significantly different from sample R-a. Samples R-b and R-c display very close isotopic values with, respectively, $\delta^{13} \mathrm{C}$ values of $+4.35 \%$ and $+4.03 \%$ V-PDB and $\delta^{18} \mathrm{O}$ values of, respectively, $+2.44 \%$ and $+2.04 \%$ V-PDB (Tab. 1). The measured ${ }^{87} \mathrm{Sr} /{ }^{86} \mathrm{Sr}$ ratios for the two samples are homogeneous at $0,707069 \pm 14 \cdot 10^{-6}$ and are consistent with an Early Bathonian or Early Tithonian age (Fig. 3).

The sample R-d was taken in the middle of a thick vein hosting equant or blocky calcite filling all remaining space (Fig. 8c). Two successive generations of calcite were identified in plane polarized light and they were attributed to $\mathrm{C} 3$ and $\mathrm{C} 4$. Unfortunately the size of the micro-drill did not allow recovering samples at two different locations and the $\mathrm{Rd}$ sample is probably a mix between $\mathrm{C} 3$ and $\mathrm{C} 4$. The isotopic analyses display a $\delta^{13} \mathrm{C}$ value of $+8.46 \%$ V-PDB and a $\delta^{18} \mathrm{O}$ value of $+1.8 \%$ V-PDB (Tab. 1). The measured ${ }^{87} \mathrm{Sr} /{ }^{86} \mathrm{Sr}$ ratio of $0,707281 \pm 14 \cdot 10^{-6}$ is crosscutting the $\mathrm{Sr}$ curve several times (Pliensbachian, Late Toarcian, Early Bajocian, Late Berriasian, Late Aptian and even Late Turonian) as shown on Figure 3.

All $\delta^{13} \mathrm{C}$ and $\delta^{18} \mathrm{O}$ isotopic values obtained from samples $\mathrm{R}-\mathrm{a}, \mathrm{R}-\mathrm{b}, \mathrm{R}-\mathrm{c}$ and $\mathrm{R}-\mathrm{d}$ are in the range of values measured in previous studies (Peckmann et al., 1999; Tribovillard et al., 2013). However, no bitumen was detected in any samples of the sub-site $\mathrm{R}$.
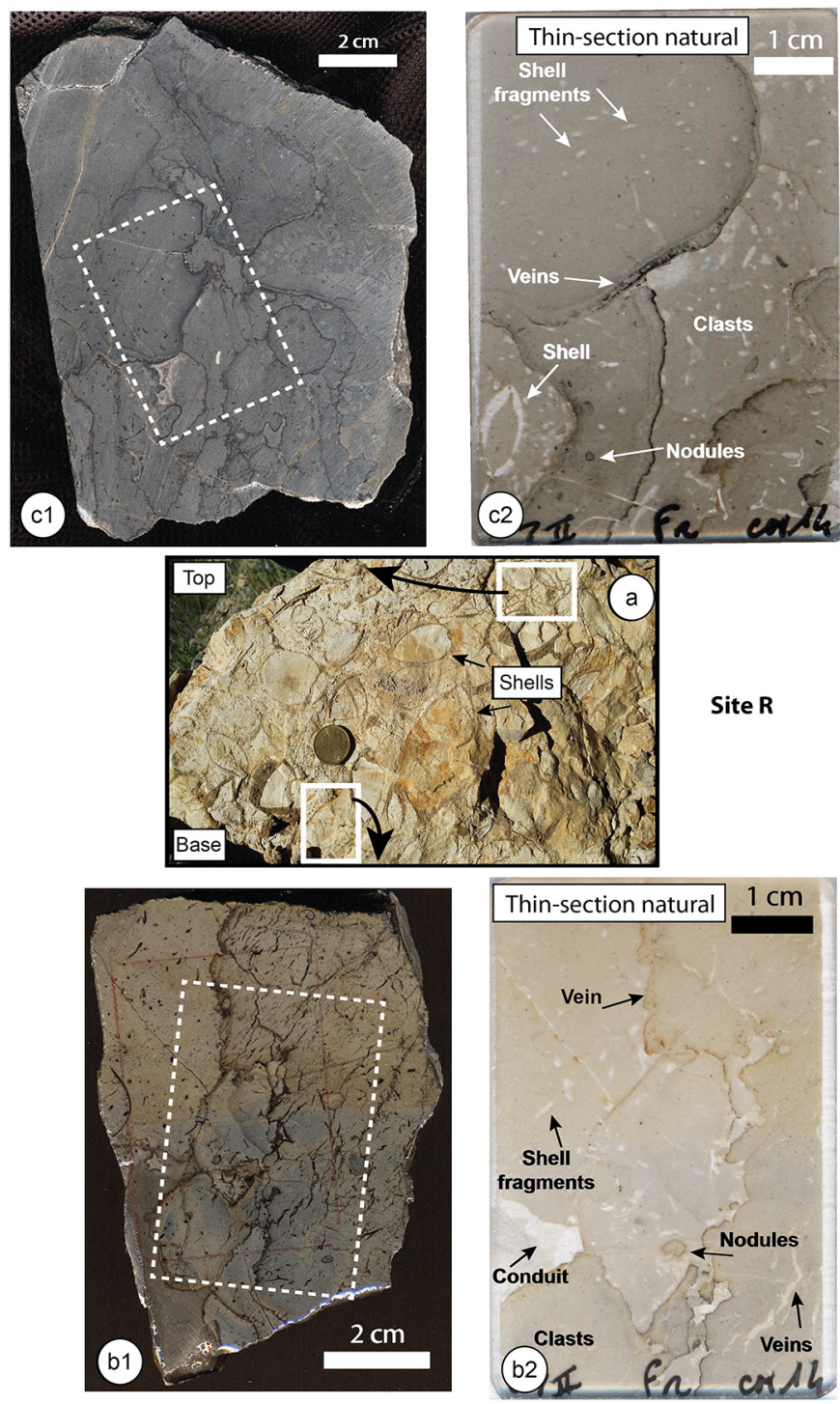

Fig. 7. (a) Detailed photograph of a carbonate lens in the sub-site R (see Fig. 5 for location) displaying densely packed 5 to $8 \mathrm{~cm}$ wide lucinid specimens encased in a nodules-rich micritic matrix. (b) Detailed photograph and its related thin-section in natural light showing unbroken shells, shell fragments, clasts and nodules in a micritic matrix. (c) Detailed photograph and its related thin-section in natural light showing conduits and veins that developed through the carbonate lens.

\section{Relation between carbonate lenses and underlying tubes, example of the seep sub- site A}

In the Beauvoisin area the sub-site A (See Fig. 2a for location) was first described as a columnar structure (Gaillard et al., 1985; Rolin, 1987). However, a recent study has shown that the sub-site A is composed of lenticular carbonate lenses with a general organization very similar to the other sub-sites B to $\mathrm{T}$, and particularly to the sub-sites E1 and R previously described in this study (Fig. 9) (Gay et al., 2019). Three units $\mathrm{A} 1, \mathrm{~A} 2$ and $\mathrm{A} 3$, respectively from base to top, were individualized as main sub-sites. They are located in the 

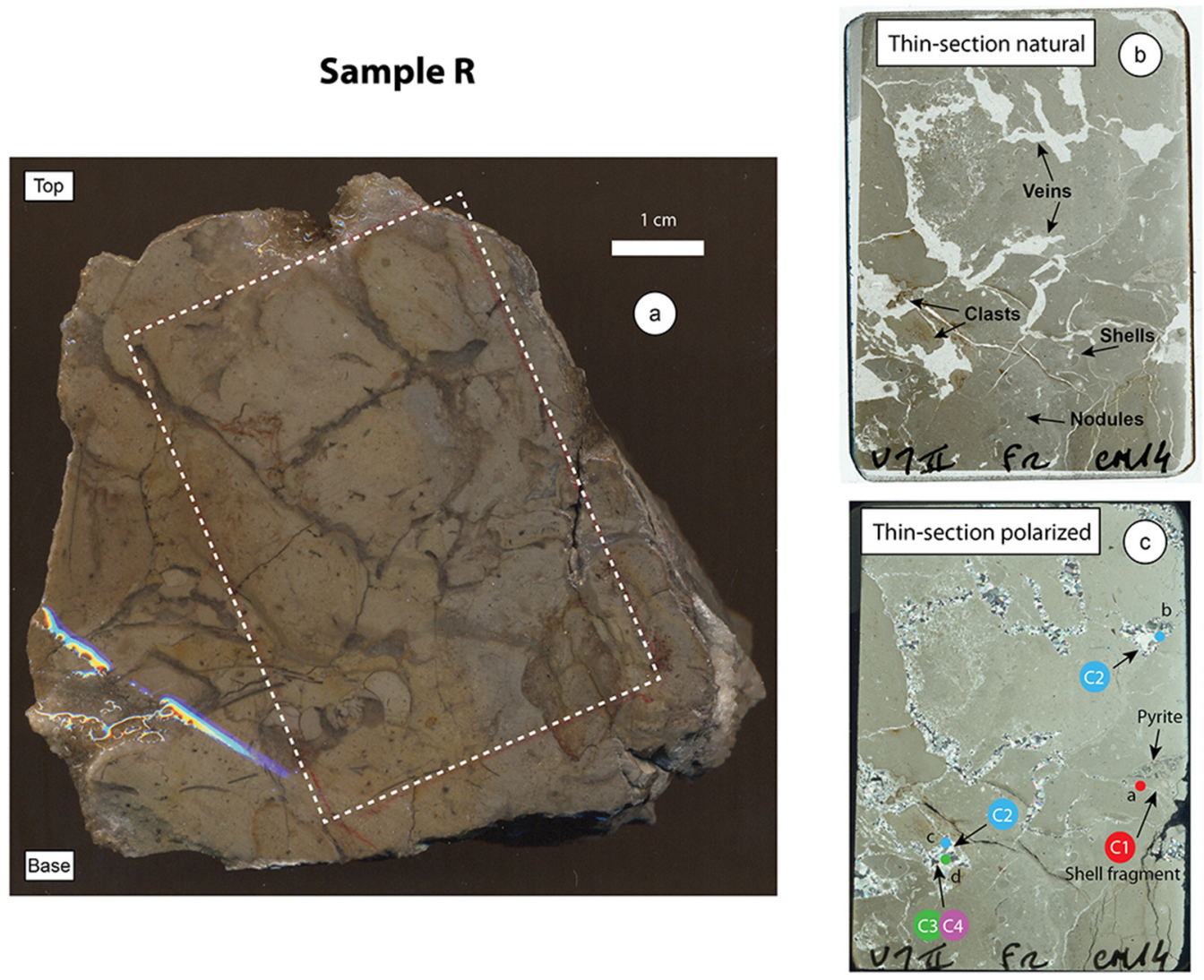

Fig. 8. (a) Detailed photograph of a brecciated carbonate lens at the base of the sub-site R (see Fig. 5 for location). (b) The thin-section natural illumination displays veins and clasts forming a jigsaw-like structure. (c) The thin-section polarized illumination shows mineralizations in veins and conduits. Four different calcites have been identified: $\mathrm{C} 1$, in red, is an iron-rich micro-sparitic calcite generally found in shell fragments or thin veins; $\mathrm{C} 2$, in blue, is a brown drusy calcite that is in contact with the micritic matrix and is usually coating clasts; $\mathrm{C} 3$, in green, and $\mathrm{C} 4$, in purple, are equant or blocky calcite filling all remaining space. Isotopic analyzes (C, O and $\mathrm{Sr}$ ) were conducted on four samples (see text for details).

Early Oxfordian interval and thus correspond to the first bioconstructions occurring in the area (See Fig. $2 \mathrm{~b}$ for log dating). They all belong to the Cordatum zone and the Cardioceras sub-zone after Gradstein (2012).

Three samples were collected in carbonate masses at various vertical positions related to the sub-site A1 (Fig. 8).

\subsection{Basal carbonate lens: sample A1}

The sample A1 was taken in the basal carbonate lens (see Fig. 9a and $9 \mathrm{~b}$ for location), which is dominated by breccia and mineralized veins, at the same position as for sub-site R. In thinsection, the sample A1 displays a micritic to microsparitic matrix, rich in detrital grains (quartz, feldspar), shell fragments (mainly lucinids and gastropods), and pyrites (about 95\% framboidal and 5\% pseudo euhedral), crossed by mm- to pluri$\mathrm{mm}$ wide mineralized veins (Fig. 10a). Depending on the concentration of bio-detritus, the matrix can locally be considered as biomicritic to biomicro-sparitic. The samples A1-a and A1-b were taken in the calcite $\mathrm{C} 1$ replacing shell fragments (Fig. 10a). In plane-polarized light, the calcite $\mathrm{C} 1$ is always crosscut by all other generations of calcite (Fig. 10b) supporting that the calcite $\mathrm{C} 1$ is the first generation of calcite occurring in the basal carbonate lens. The samples A1-a and A1b have $\delta^{13} \mathrm{C}$ values of $-9.82 \%$ and $-12.01 \%$ V-PDB respectively and $\delta^{18} \mathrm{O}$ values of $-4.16 \%$ and $-6.08 \%$ V-PDB respectively (Tab. 1). The measured ${ }^{87} \mathrm{Sr} /{ }^{86} \mathrm{Sr}$ ratios of $0.706896 \pm 10.10^{-6}$ and $0.706802 \pm 14.10^{-6}$ for both samples are consistent with an Early Oxfordian or Middle Oxfordian age. The samples A1-c to A1-g were taken in the light brown drusy calcite $\mathrm{C} 2$ which is in contact with the micritic matrix in most places along the major vein or locally coating clasts. In details, the calcite $\mathrm{C} 2$ in contact with the matrix is microsparitic and becomes more drusy towards the center of the vein as shown in the plane-polarized section (Fig. 10b). Cathodoluminescence microscopic image does not exhibit any clear evidences for the limit between the matrix and the calcite C2 (Fig. 10b). The average value of $\delta^{13} \mathrm{C}$ is $+16.54 \mathrm{~V}-\mathrm{PDB}$ and the average value of $\delta^{18} \mathrm{O}$ is $-0.51 \%$ V-PDB. The measured ${ }^{87} \mathrm{Sr} /{ }^{86} \mathrm{Sr}$ ratio of $0.707045 \pm 10.10^{-6}$ for A1-c gives an age of Early Bathonian or Early Tithonian. The samples A1-h and A1-i were taken in the equant calcite $\mathrm{C} 3$ in the major vein (Fig. 10a). The calcite $\mathrm{C} 3$ is always in contact with the calcite $\mathrm{C} 2$ but never in contact with the micritic matrix as shown in the plane polarized section (Fig. 10b). Contrary to the natural light showing a difference in color between the light brown calcite $\mathrm{C} 2$ and the light yellowish calcite $\mathrm{C} 3$, the cathodoluminescence shows that the limit is not as clear (Fig. 10b). The drusy calcite C2 is locally passing to a more equant calcite $\mathrm{C} 3$. The average value of $\delta^{13} \mathrm{C}$ is $+9.43 \mathrm{~V}$-PDB and the average value of $\delta^{18} \mathrm{O}$ is $1.62 \%$ 
Table 1. Isotopic values of $\mathrm{C}$ and $\mathrm{O}$ measured on thin sections using a micro-drill and depending on the phase of calcite (C1 to $\mathrm{C} 5)$ identified on thin sections. The $\delta 13 \mathrm{C}$ and $\delta 18 \mathrm{O}$ ratios are precise to $\pm 0.02 \%$ and $\pm 0.04 \%$ respectively. The $87 \mathrm{Sr} / 86 \mathrm{Sr}$ isotopic ratios are provided with the $2 \delta$ error bar.

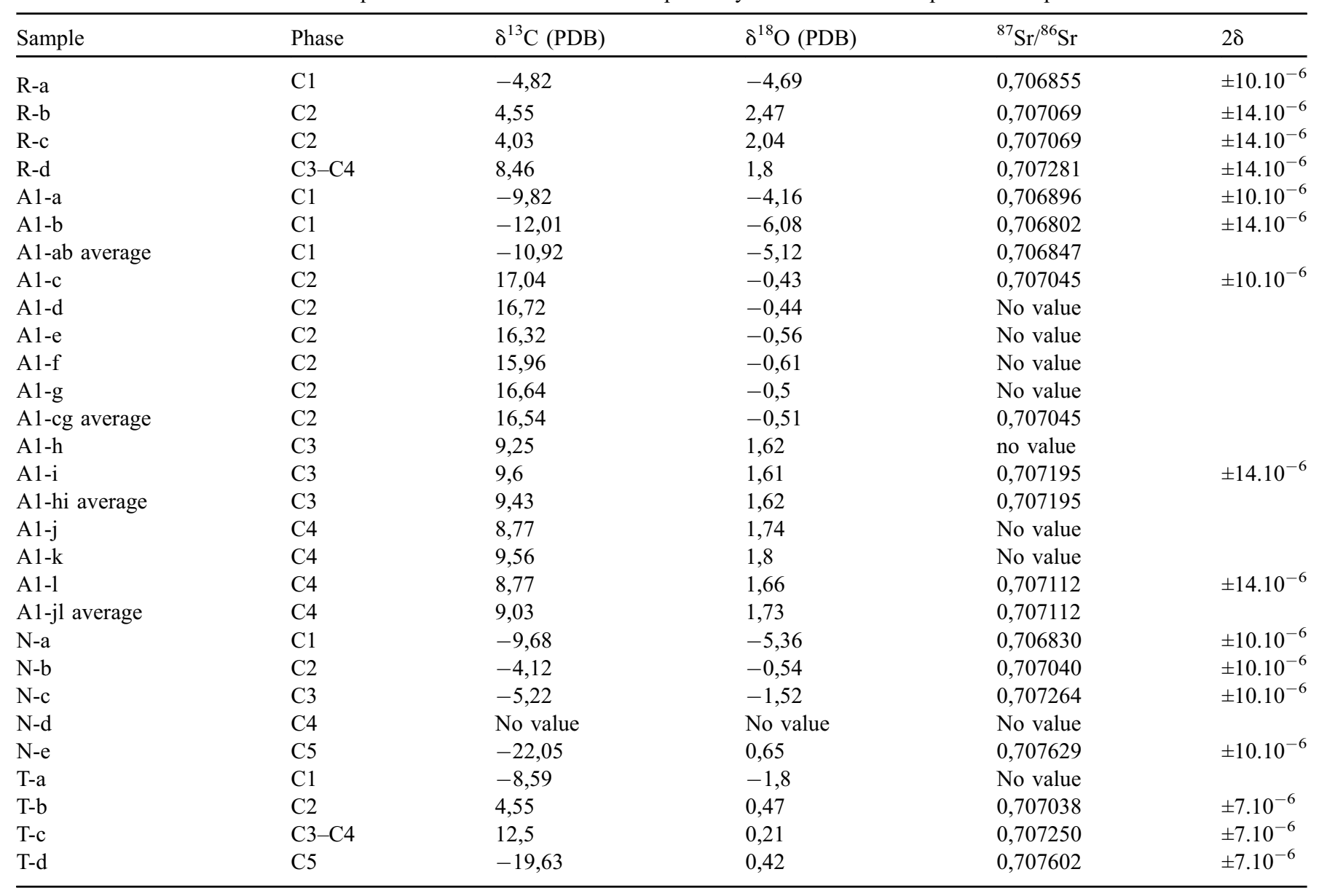

V-PDB. The average measured ${ }^{87} \mathrm{Sr} /{ }^{86} \mathrm{Sr}$ ratio of $0.707195 \pm 14.10^{-6}$ crosscut the $\mathrm{Sr}$ curve several times (Pliensbachian, Middle Toarcian, Middle Bajocian, Early Berriasian and Late Aptian) as shown on Figure 3. The samples A1-j to A1-1 were taken in the white calcite C4 in the middle of the main vein (Fig. 10a). Where the calcite $\mathrm{C} 4$ is in contact with the calcite C3 it appears fibrous (Fig. 10b). As shown in the cathodoluminescence, the calcite $\mathrm{C} 4$ may locally be the result of the recrystallization of $\mathrm{C} 3$ in thin veins where it becomes more microsparitic (Fig. 10b). Towards the center of the major vein, the calcite $\mathrm{C} 4$ becomes more equant or blocky, filling all remaining space. The average value of $\delta^{13} \mathrm{C}$ is $+9.03 \%$ V-PDB and the average value of $\delta^{18} \mathrm{O}$ is $1.73 \% \mathrm{~V}$ PDB. Only the sample A1-1 was analyzed to get the ${ }^{87} \mathrm{Sr} /{ }^{86} \mathrm{Sr}$ ratio yielding a value of $0.707112 \pm 14.10^{-6}$. This value crosscuts the Sr curve several times (Pliensbachian, Early Toarcian, Late Bajocian and Late Tithonian). In the sample A1, a last generation of a white microsparitic calcite (C5) was identified in thin veins crosscutting all previous generations of calcite $(\mathrm{C} 1-\mathrm{C} 4)$ and the micritic matrix.

\subsection{Carbonate nodule: sample $\mathbf{N}$}

The sample $\mathrm{N}$ was taken in a $15 \mathrm{~cm}$ wide carbonate mass at about $5 \mathrm{~m}$ beneath the basal lens of the sub-site A1 (see Fig. 9a and 9c for location). Its shape is very irregular and not well-rounded. It is part of an aggregate of several masses as shown in Gay et al. (2019). In cross section the carbonate mass displays a homogeneous micrite encasing some 1 to $3 \mathrm{~cm}$ size well-preserved shells and dispersed pluri-mm size nodules (Fig. 11a). Its composition is very similar to that of sample A1 but it appears richer in pyrite based on surface distribution. Very close to the edge of the mass the micritic matrix is brecciated by a $2 \mathrm{~cm}$ wide mineralized vein forming a jigsaw-like structure. Some clasts were incorporated into the mineralized vein as shown in thin-section (Fig. 11b). Even nodules in the close vicinity of the vein are brecciated. The samples $\mathrm{N}-\mathrm{a}$ to $\mathrm{N}-\mathrm{d}$ were analyzed in respect to the calcites $\mathrm{C} 1$ to $\mathrm{C} 5$ (Fig. 11b). For the sample $\mathrm{N}-\mathrm{a}(\mathrm{C} 1)$ the value of $\delta^{13} \mathrm{C}$ is $-9,68 \% \mathrm{~V}-\mathrm{PDB}$ and the value of $\delta{ }^{18} \mathrm{O}$ is $-5,36 \% \mathrm{~V}-\mathrm{PDB}$. The measured ${ }^{87} \mathrm{Sr} /{ }^{86} \mathrm{Sr}$ ratio of $0.706830 \pm 10.10^{-6}$ gives an estimated age of Early Oxfordian to Middle Oxfordian. The sample N-b (C2) gives a $\delta^{13} \mathrm{C}$ value of $-4,12 \%$ V-PDB and a $\delta^{18} \mathrm{O}$ value of $-0,54 \%$ V-PDB. The measured ${ }^{87} \mathrm{Sr} /{ }^{86} \mathrm{Sr}$ ratio of $0.707040 \pm 10.10^{-6}$ gives an estimated age of Middle Bathonian or Early Tithonian. The sample N-c (C3) gives a $\delta^{13} \mathrm{C}$ value of $-5,22 \%$ V-PDB and a $\delta^{18} \mathrm{O}$ value of $-1,52 \%$ V-PDB. The measured ${ }^{87} \mathrm{Sr} /{ }^{86} \mathrm{Sr}$ ratio of $0.707264 \pm 10.10^{-6}$ crosscuts the Sr curve several times (Pliensbachian, Late Toarcian, Early 


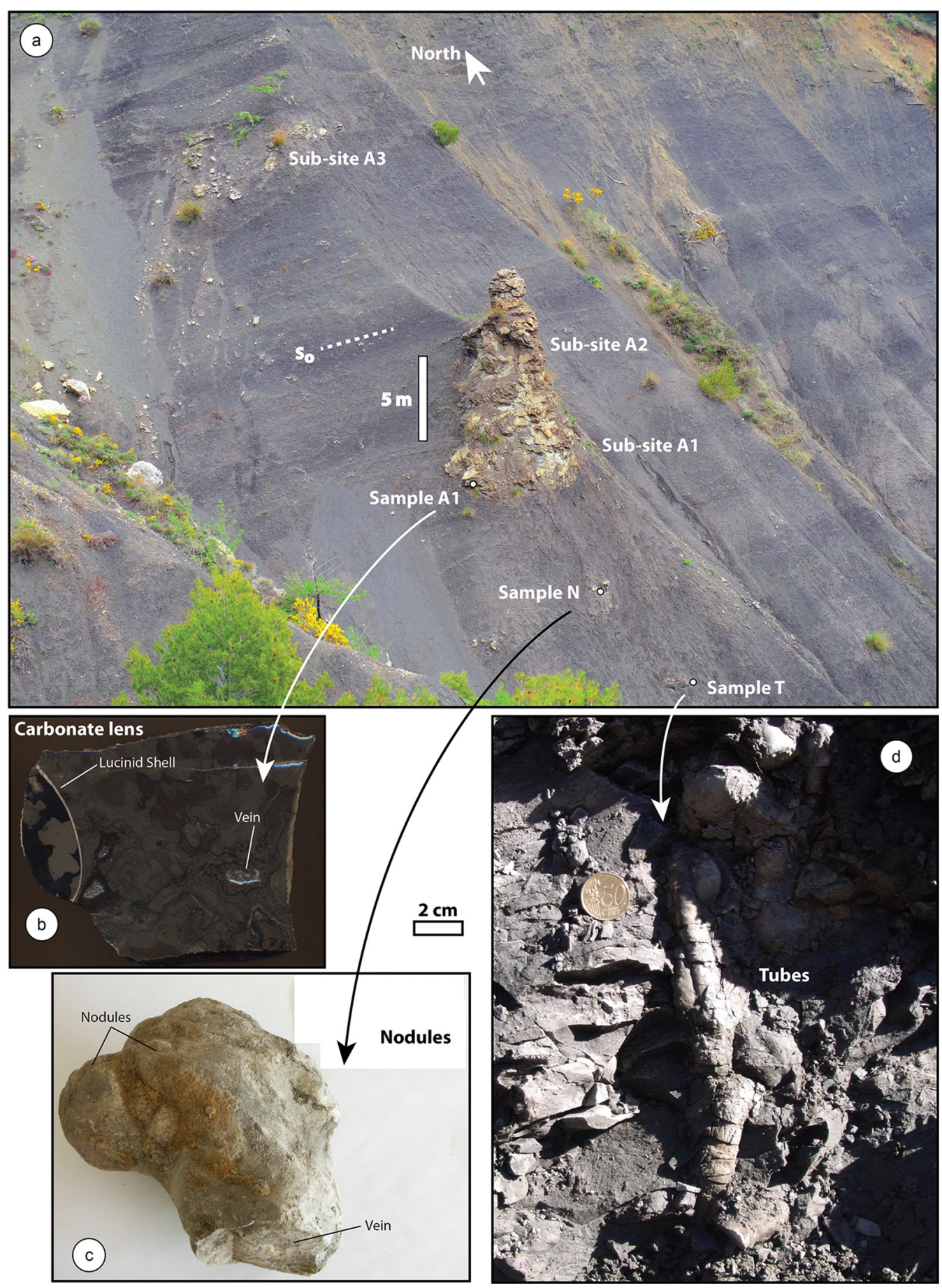

Fig. 9. (a) Outcrop photograph to the North-East of the sub-site A located in the Cordatum zone (Early Oxfordian). The sub-site A is composed of three main units, A1, A2 and A3 from the base to the top. Three samples have been collected: (b) in the basal lens of the sub-site A1 (sample A1), (c) in nodules (sample N) located about $5 \mathrm{~m}$ beneath, and (d) in tubes (sample T) located about $10 \mathrm{~m}$ beneath compared to regional stratigraphy So.

Bajocian, Late Berriasian and Late Aptian) as shown on Figure 3. Unfortunately the sample N-d, taken in the calcite C4 did not provide any data due to technical issues. As for the sample A1 in the overlying basal lens, the white microsparitic calcite $\mathrm{C} 5$ is crosscutting previous phases of calcite precipitation (Fig. 11b). However, it also appears as blocky calcite with 10 to $15 \mathrm{~mm}$ wide crystals filling all remaining space in the central conduit. Hydrocarbon has been locally found in the connected porosity between calcite $\mathrm{C} 5$ crystals. The sample $\mathrm{N}-\mathrm{e}(\mathrm{C} 5)$ gives a $\delta^{13} \mathrm{C}$ value of $-22,05 \%$ V-PDB and a $\delta^{18} \mathrm{O}$ value of $0,65 \% \mathrm{~V}-\mathrm{PDB}$. The measured ${ }^{87} \mathrm{Sr} /{ }^{86} \mathrm{Sr}$ ratio of $0.707629 \pm 10.10^{-6}$ gives an estimated age of Trias, Early Sinemurian or Late Campanian (Fig. 3). 


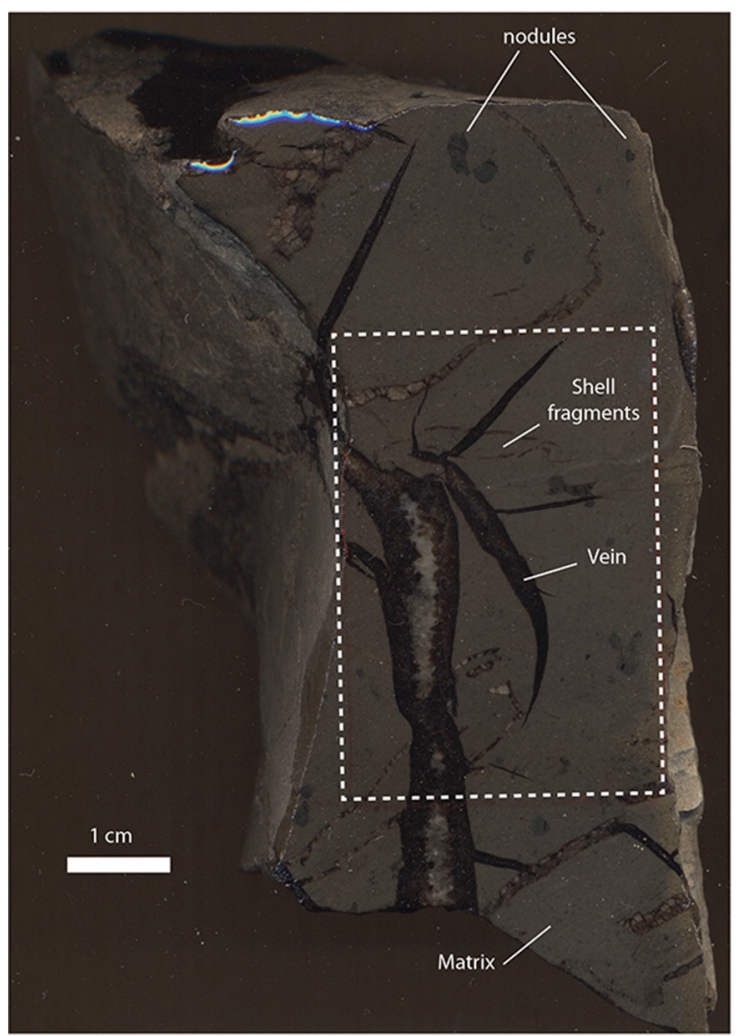

\section{Sample A1}
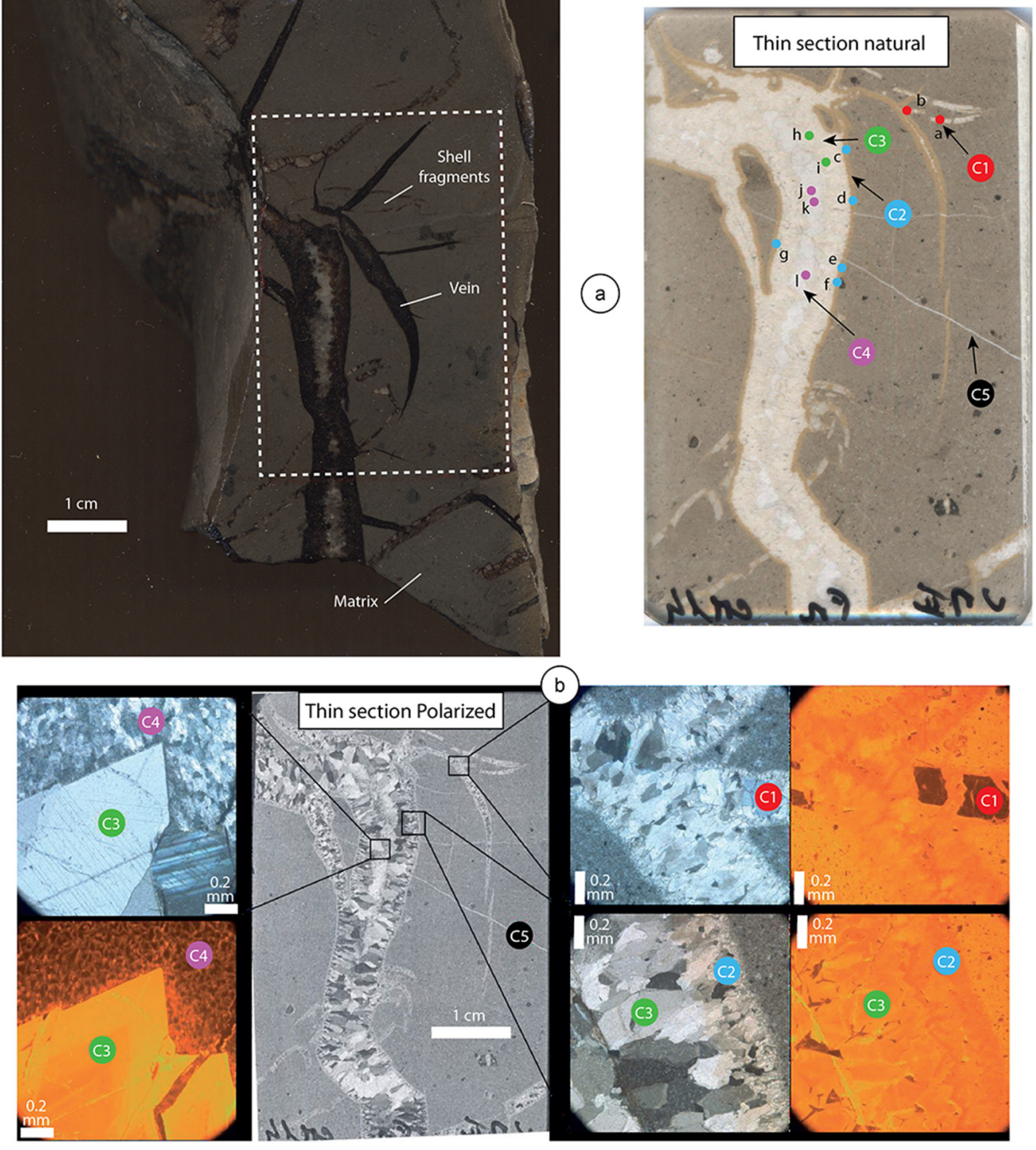

Fig. 10. (a) Detailed photograph of sample A1 and its related thin-section in natural light. The sample A1 is dominated by breccia and mineralized veins in a micritic to microsparitic matrix rich in shell fragments. (b) The thin-section natural light and polarized illuminations coupled to Raman analyzes display five different calcites: C1, in red, is a micro-sparitic calcite replacing shell fragments; C2, in blue, is a lightbrown drusy calcite which is microsparitic when in contact with the micritic matrix and becomes more drusy towards the centre of the vein; $\mathrm{C} 3$, in green, is an equant calcite, always in contact with the calcite $\mathrm{C} 2$ but never in contact with the micritic matrix; $\mathrm{C} 4$, in purple, is a white equant or blocky calcite filling all remaining space in the veins; C5, in black, is a white microsparitic calcite present in veins crosscutting all previous generations. They were isotopically analyzed for $\mathrm{C}, \mathrm{O}$ and $\mathrm{Sr}$ on 12 samples (see text for details and Tab. 1 for values).

\subsection{Carbonate tube: sample T}

The sample T corresponds to a tubular carbonate mass, $30 \mathrm{~cm}$ high and $20 \mathrm{~cm}$ in diameter, found about $10 \mathrm{~m}$ beneath the basal lens of the sub-site A1 and about $5 \mathrm{~m}$ beneath the sample $\mathrm{N}$ (see Fig. 9a and 9d for location). It contains numerous nodules encased in a micritic matrix (Fig. 12a). Rare lucinid shells of 1 to $3 \mathrm{~cm}$ maximum size were also identified. It is characterized by a large number of mineralized veins and a 1 to $2 \mathrm{~cm}$ wide central vein in its center. A void is clearly visible both in thin-section and in cross-polarized illumination (Fig. 12b, c). This sample is affected by intense fracturing and defining the phases remained unclear in some places as the clasts and veins are crosscut several times by other veins. However, the surrounding marls are not affected by the fractures. In this context, the sample T-a was taken in a calcite $\mathrm{C} 1$ surrounded by the calcite $\mathrm{C} 2$. This sample $\mathrm{T}-\mathrm{a}(\mathrm{C} 1)$ 


\section{Sample N}
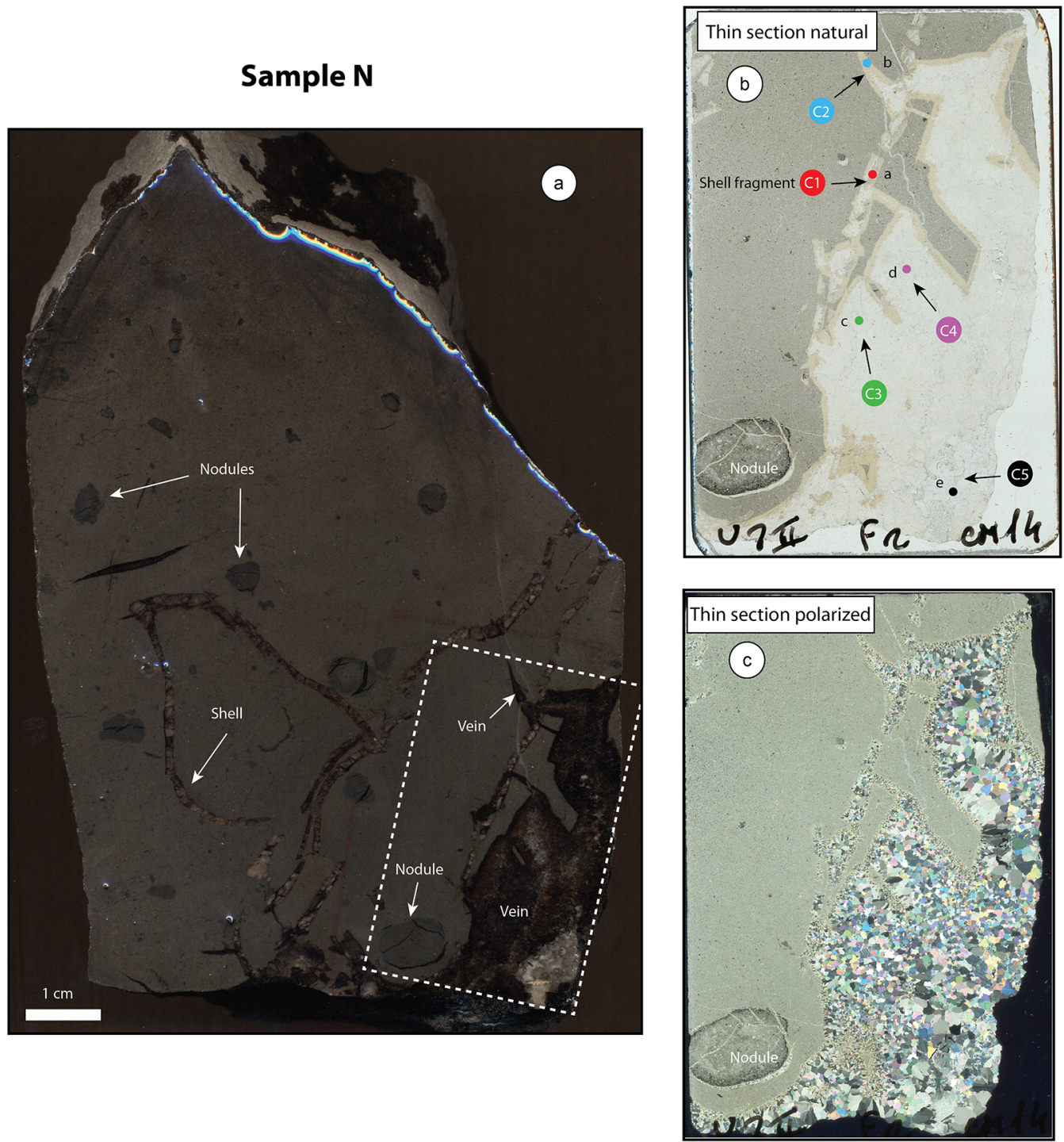

Fig. 11. (a) Detailed photograph of sample N showing well-preserved lucinid shells and pluri-mm nodules dispersed in an homogeneous micritic matrix. (b) and (c) Thin-section natural and polarized light illuminations showing clasts incorporated in a large mineralized vein. Five calcites $\mathrm{C} 1$ to $\mathrm{C} 5$ are very similar to the calcites identified in sample A1. Isotopic analyzes (C, O and $\mathrm{Sr}$ ) were conducted on five samples (see text for details and Tab. 1 for values)

gives a $\delta^{13} \mathrm{C}$ value of $-8,59 \%$ V-PDB and a $\delta^{18} \mathrm{O}$ value of $-1,8 \%$ V-PDB. Locally, strontianite has been identified between the calcites $\mathrm{C} 1$ and $\mathrm{C} 2$. The sample T-b was taken in the drusy calcite $\mathrm{C} 2$, which is in direct contact with the micritic matrix. It gives a $\delta^{13} \mathrm{C}$ value of $+4,55 \%$ V-PDB and a $\delta^{18} \mathrm{O}$ value of $+0,47 \%$ V-PDB. The measured ${ }^{87} \mathrm{Sr} /{ }^{86} \mathrm{Sr}$ ratio of $0.707038 \pm 7.10^{-6}$ gives an estimated age of Middle Bathonian or Late Kimmeridgian. In the tube, it is very difficult to distinguish the calcite $\mathrm{C} 3$ from the calcite $\mathrm{C} 4$ as they are not very well developed. However, both phases can be found in the middle part of veins in contact with $\mathrm{C} 2$. The sample T-c $(\mathrm{C} 3-\mathrm{C} 4)$ has a $\delta^{13} \mathrm{C}$ value of $+12,5 \%$ V-PDB and a $\delta^{18} \mathrm{O}$ value of $+0,47 \%$. V-PDB. The measured ${ }^{87} \mathrm{Sr} /{ }^{86} \mathrm{Sr}$ ratio of $0.707250 \pm 7.10^{-6}$ could be related to several ages (Pliensbachian, Late Toarcian, Early Bajocian, Late Berriasian, Late Aptian) as shown on Figure 3. As for the nodule N, a calcite (C5) has been identified in the middle of the conduit and in some few $\mathrm{mm}$ wide thin veins. In fact, this phase displays large crystals of 10 to $15 \mathrm{~mm}$ wide equant calcite growing towards the center where the remaining void is present (Fig. 12c). The sample T-d (C5) has a $\delta^{13} \mathrm{C}$ value of $-19,63 \%$ V-PDB and a $\delta^{18} \mathrm{O}$ value of $+0,42 \%$ V-PDB. The measured ${ }^{87} \mathrm{Sr} /{ }^{86} \mathrm{Sr}$ ratio of $0.707602 \pm 7.10^{-6}$ gives an estimated age of Trias, Early Sinemurian or Late Campanian. The calcite C5 can locally contain traces of hydrocarbons or bitumen identified both on Raman and SEM, as previously shown by Peckmann et al. (1999) in this area. In two Early and Middle Oxfordian samples, the gas chromatograms $(\mathrm{C} 13+)$ yielded n-alkanes with chain lengths from 12 to 33 carbons, indicating that the fluids originated from the thermal maturation of organic matter. They also show isotopic signatures typical of petroleum hydrocarbons derived from planktonic or detrital sources with $\delta{ }^{13} \mathrm{C}$ values of $-67,5 \%$ and $-75,7 \%$ V-PDB (Peckmann et al., 1999). 

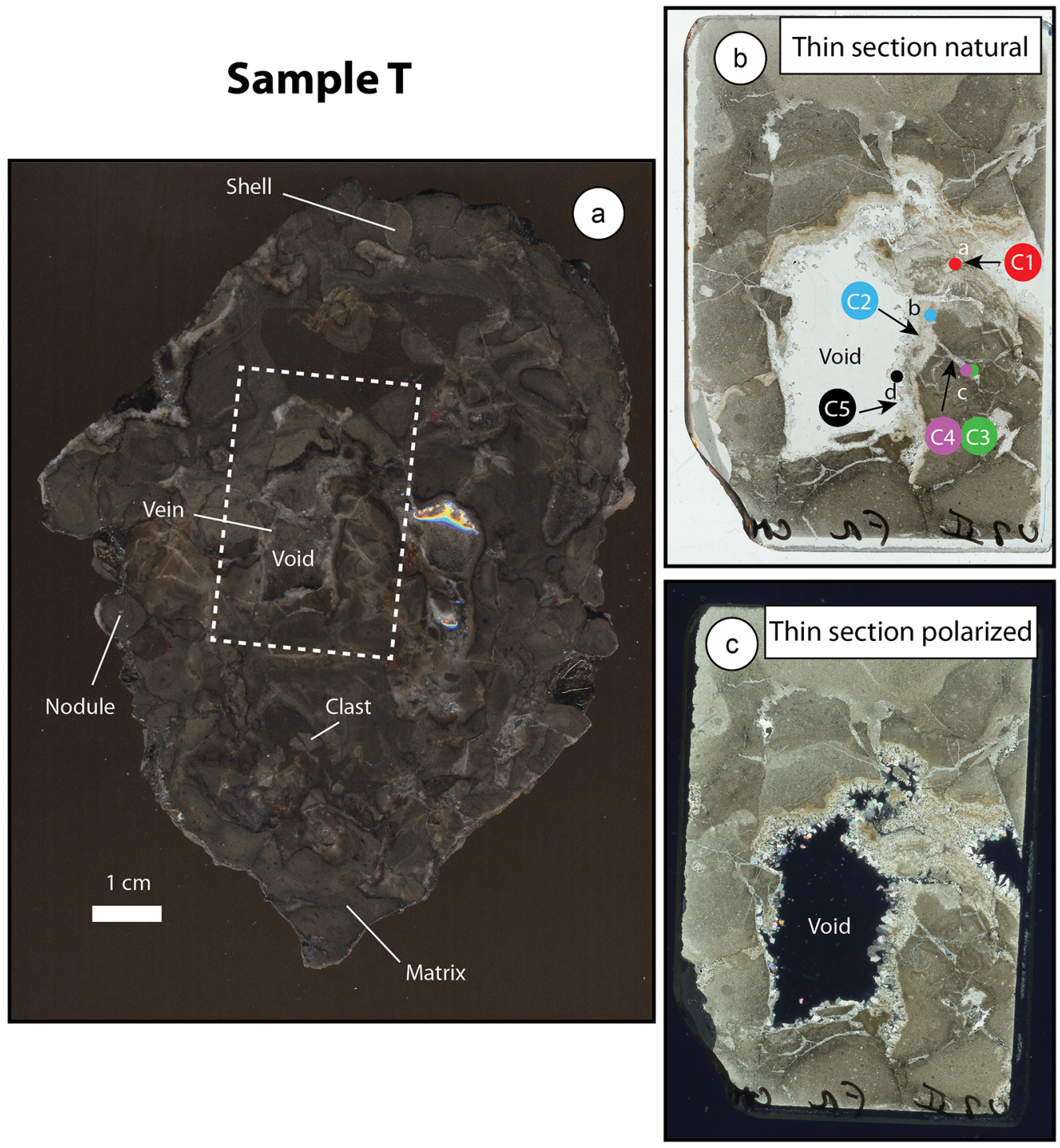

Fig. 12. (a) Detailed photograph of sample $T$ displaying numerous clasts and a large void, about 1 by $2 \mathrm{~cm}$, in the centre of the tube. (b) and (c) Thin-section natural and polarized light illuminations showing the five previously identified calcites $\mathrm{C} 1$ to $\mathrm{C} 5$. The calcite $\mathrm{C} 1$ is replacing shell fragments whereas the calcites $\mathrm{C} 2$ to $\mathrm{C} 5$ are concentrically arranged from the periphery to the centre of the void. The white equant calcite $\mathrm{C} 5$ locally contains traces of hydrocarbons or bitumen in veins as previously shown by Peckmann et al. (1999) in the area. Isotopic analyzes (C, O and $\mathrm{Sr}$ ) were conducted on four samples (see text for details and Tab. 1 for values).

\section{Discussion}

\subsection{Sub-site organization}

A recent study on the same area has shown that a single sub-site (A to $\mathrm{T}$ ) is generally organized as a set of vertically stacked carbonate lenses interbedded with marls or claystones (Gay et al., 2019). Each sub-site is located in the center of a concentric area of nodules forming a $100-120 \mathrm{~m}$ wide depression, 4 to $6 \mathrm{~m}$ in depth compared to the surrounding palaeo-seafloor. Although the carbonate lenses contain reefbuilding organisms it is now considered that they did not form any significant relief on the seafloor (Gaillard et al., 1985; Rolin, 1987; Peckmann et al., 1999; Gay, 2002) even if some examples on modern sites show that they can form a positive relief (up to $10 \mathrm{~m}$ ) above the seabed (Teichert et al., 2005; Haas et al., 2010; Himmler et al., 2015). It has been shown that carbonate pavements formed in situ into the sediments (Bayon et al., 2009).

The sub-sites correspond to seven clusters of pseudobioherms and only one cluster was active at a given time. The seepage activity was spread over time, cluster after cluster. The spatio-temporal 3D reconstruction of the position of these clusters shows that the coalescence of the clusters led to the formation of a $800 \mathrm{~m}$ wide giant fossil pockmark in about 3.4 My. However, periods of fluid seeping alternated with periods of apparent quiescence, about $200 \mathrm{ky}$ each (Gay et al., 2019). During the period of apparent quiescence, the reduced fluid flux in the shallow sub-surface could not sustain massive carbonate precipitation, but it does not mean that the fluid flux was also reduced at depth, with possible lateral migrations 


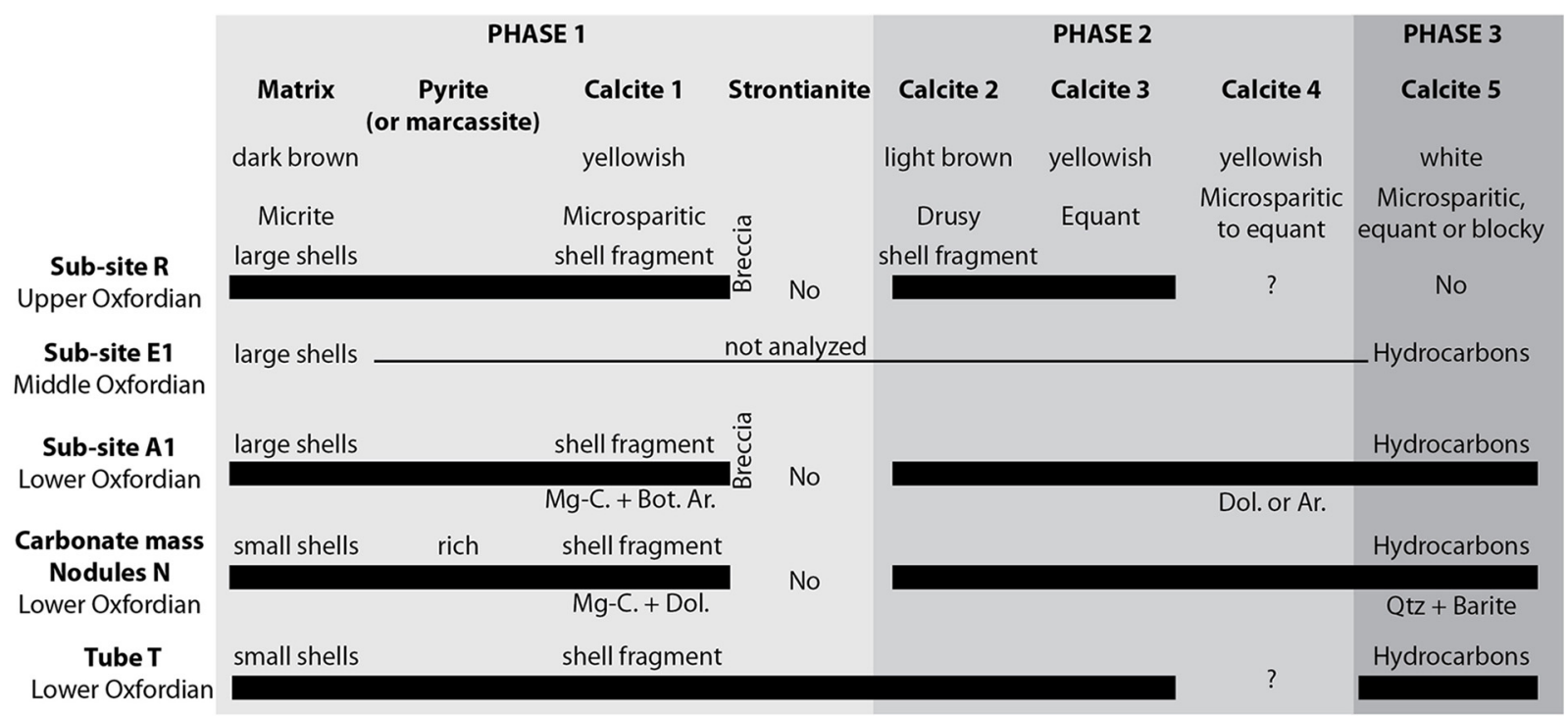

Fig. 13. Diagram of paragenesis in the three studied sub-sites A1 (including the tube T, the nodule $N$ and the basal carbonate lens A1), E1 and R. It shows very similar paragenis characterized by a dark-brown micritic matrix with well-preserved shells or shell fragments replaced by calcite $\mathrm{C} 1$ (or aragonite) and disseminated pyrite (or marcasite). The light-brown drusy calcite $\mathrm{C} 2$ developed in contact with the micritic matrix. The equant calcite $\mathrm{C} 3$ and the microsparitic to equant calcite $\mathrm{C} 4$ (locally dolomite or aragonite) are in contact with the calcite $\mathrm{C} 2$ and appear cleaner, suggesting that this is the same continuous process of mineralization. The white microsparitic to blocky calcite C5 was identified in all sampling sites except R. Hydrocarbons or bitumen were evidenced in veins between C5 crystals only and as inclusions within the crystals or in quartz present in nodules. They were not evidenced above sub-site E1.

perturbating the zone beneath the giant pockmark, which gave birth to a new cluster of sub-sites at a different location in the general depression of the pockmark (Gay et al., 2019). To date all sub-sites were considered as individual pockmarks (Gaillard et al., 1985; Rolin, 1987) and carbonate lenses alternating with marls were considered to be the result of varying fluid fluxes as observed in modern sites (Feng et al., 2010). However, the well exposed sub-site E1 clearly shows that the carbonate lenses are lenticular in shape, laterally passing to the marls where nodules are abundant close to the carbonate lens. The thickest part of an overlying carbonate lens is systematically located where the underlying carbonate lens is thinning or absent, suggesting that the fluids allowing the massive carbonate precipitation were, at some point, deviated to be expelled laterally in any possible direction beneath the sub-site acting as a seal and leading to a new carbonate lens at seafloor. The basal lenses are composed of a breccia made of mineralized veins, clasts-rich conduits crosscutting limestones and embedded nodules whereas the overlying lenses are richer in macrofauna, such as lucinids, but are less affected by brecciation. This facies is very similar to the "brecciated limestone" from Italy (Ladanza et al., 2013). It means that the continuous fluid supply from below the sub-site could not shift laterally anymore. The overpressured fluids were trapped and could get through the basal lenses after having brecciated them.

\subsection{Paragenesis}

The detailed study of thin-sections evidenced similar paragenesis for sub-sites $\mathrm{Al}$ and $\mathrm{R}$, nodules $\mathrm{N}$ and tubes $\mathrm{T}$ (Fig. 13). They are all characterized by a dark brown micritic matrix containing well-preserved shells of various sizes, depending on their position in the carbonate lens, shell fragments made of calcite $\mathrm{Cl}$ (or aragonite) and disseminated pyrite (or marcasite) identified on Raman and on thin-sections. The isotopic analyses conducted on both sub-sites have shown that the isotopic signature of the calcite $\mathrm{C} 1$ in shell fragments are very similar with depletion in $\delta^{13} \mathrm{C}(-10,92$ and $-14,82 \%$ respectively) and in $\delta^{18} \mathrm{O}(-5,12$ and $-4,69 \%$ respectively). These values are consistent with recent geochemical analyses conducted on several Beauvoisin sub-sites that have led to the conclusion that they were dependent on chemosynthesis through AOM (Peckmann et al., 1999; Tribovillard et al., 2013). This conclusion is also supported by specific enrichments in Mo, As and Sb in carbonate lenses evidenced in the sub-site F (Tribovillard et al., 2013), or such as in the modern mud-volcano of the Malta Plateau (Cangemi et al., 2010).

Filamentous bacterial mats are of primary importance in cold seep sites where they form laminations, mineralized biofilms, crusts, tufs, peloidal fabrics, pyrite framboids, aragonite botryoids and crystal aggregates (Cavagna et al., 1999; Aharon, 2000; Clari and Martire, 2000; Peckmann et al., 2001; Barbieri and Cavalazzi, 2005). At the Beauvoisin subsites the activity of sulfate-reducing bacteria is also indicated by the dispersively-distributed framboidal pyrite identified both on thin-sections and in SEM (Scanning Electron Microscopy). Their concentration is particularly high within nodules N (Gaillard et al., 1992; Gay, 2002) and they are considered to be of diagenetic origin (Bréheret, 1994). These observations have led to the conclusion that pyrite and calcite $\mathrm{C} 1$ are contemporaneous and formed soon after the deposition of the micritic matrix.

The pyrite-C1 phase is then followed by a period of brecciation as shown by broken shells included in clasts. The shape of clasts is concordant with the massive matrix of the 


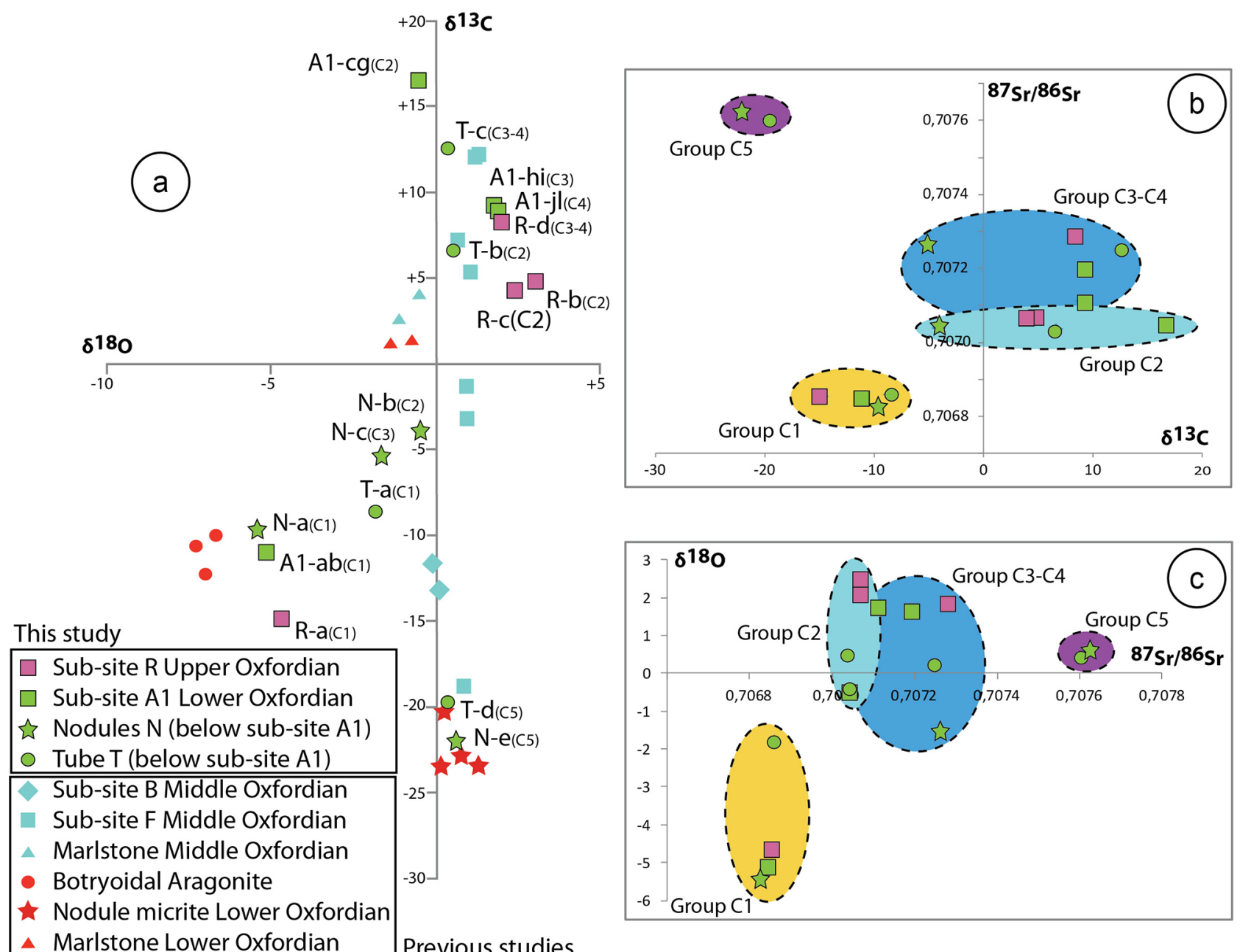

Fig. 14. (a) Diagram of $\delta^{13} \mathrm{C}$ versus $\delta^{18} \mathrm{O}$ including analyzes conducted in previous studies (Peckmann et al., 1999; Louis-Schmid et al., 2007; Tribovillard et al., 2013). The yellowish calcite $\mathrm{C} 1$ and botryoidal aragonite can be interpreted as bacterial in origin and negative isotopic values are a marker of the microbial mediation in the building of carbonate lenses. The isotopic values for $\mathrm{C} 2, \mathrm{C} 3$ and $\mathrm{C} 4$ are more dispersed with positive $\delta{ }^{13} \mathrm{C}$ and $\delta{ }^{18} \mathrm{O}$ values except for two samples that are closer to the $\mathrm{C} 1$ signature. The very negative $\delta^{13} \mathrm{C}$ isotopic values for $\mathrm{C} 5$ suggest that the same hydrocarbon-bearing fluid migrated through the tube and nodule and probably through the basal lens of sub-site A1 and all other sub-sites up to sub-site E1, but not higher as no hydrocarbons were identified above (including the sub-site R). (b) and (c) Diagrams of ${ }^{87} \mathrm{Sr} /{ }^{86} \mathrm{Sr}$ versus $\delta^{18} \mathrm{O}$ and $\delta^{13} \mathrm{C}$ versus ${ }^{87} \mathrm{Sr} /{ }^{86} \mathrm{Sr}$ showing three main groups. The group $\mathrm{C} 1$ in which the age of formation corresponds to the biostratigraphic age of the host formation (Early Oxfordian for tube T, nodule $\mathrm{N}$ and carbonate lenses in the sub-site A1 and Late Oxfordian for the sub-site R). The groups $\mathrm{C} 2$ and $\mathrm{C} 3-\mathrm{C} 4$ have very close $\mathrm{Sr}$ isotopic signatures. They formed shortly after the brecciation at a relatively shallow burial $(<1000 \mathrm{~m})$ with fluids coming from underlying Pliensbachian, Late Toarcian or Bajocian levels in a single migration event possibly dated of Cretaceous. The group $\mathrm{C} 5$ has a signature of fluids from Trias, but the migration probably occurred during the main salt diapir rising dated of the Mio-Pliocene.

carbonate lenses suggesting a jigsaw-like structure (Gay et al., 2019). A dark brown cement-supported micro-breccia is more concentrated towards the veins and the clasts in the brecciated basal lenses are systematically clotted with a light brown drusy calcite $\mathrm{C} 2$. The calcite $\mathrm{C} 2$ displays a very different isotopic signature with positive values of $\delta^{13} \mathrm{C}(+17,04 \%$ at maximum for $\mathrm{A} 1$ and $+4,55 \%$ at maximum for $\mathrm{R}$ ) and less depleted values or slightly positive values of $\delta^{18} \mathrm{O}(-0,51 \%$ on average for $\mathrm{A} 1$ and $+2,47 \%$ at maximum for $\mathrm{R}$ ). These values are much closer to the isotopic signature of marls in the area both for site A1 and T respectively (Peckmann et al., 1999; Tribovillard et al., 2013). This not necessarily means that the fluid that initiated the first carbonate lenses and precipitated in shells to form the calcite $\mathrm{C} 1$ was different from the fluid that led to the brecciation and then the precipitation of the drusy calcite $\mathrm{C} 2$ around clasts, but this could mean that the second phase came from long-lasting fluids trapped beneath the subsite and that became more in equilibrium with surrounding marls before they were expelled due to overpressure causing the brecciation. Locally strontianite was identified in replacement of calcite $\mathrm{C} 2$ in the nodules $\mathrm{N}$ and in the tube $\mathrm{T}$. This suggests that an additional Sr-rich fluid may have caused the brecciation beneath the sub-site A1. However, this is not the case for the sub-site $\mathrm{R}$ where strontianite was not evidenced. 
The subsequent yellowish equant calcite $\mathrm{C} 3$ and microsparitic to equant calcite C4 (locally dolomite or aragonite) grew up in contact with $\mathrm{C} 2$ towards the middle of the veins and they are never in direct contact with the micritic matrix or the calcite $\mathrm{C} 1$. The size and shape of crystals suggest slow processes of precipitation, probably due 1) to slow motion of fluids (compared to $\mathrm{C} 2$ ) within the veins in sub-sites $\mathrm{A} 1$ and $\mathrm{R}$, the nodules in carbonate masses $\mathrm{N}$ and conduits in the tube $\mathrm{T}$ and 2) to the continuous supply of fluids of the same nature.

The last phase corresponds to a white microsparitic to blocky calcite $\mathrm{C} 5$. The calcite $\mathrm{C} 5$ was not identified in the subsite R. In the carbonate lenses of the sub-site A1 the calcite C5 is only microsparitic in small straight veins crosscutting all previous phases $\mathrm{C} 1$ to $\mathrm{C} 4$. It is more blocky in the carbonate masses forming the nodules where it always filled all remaining space in veins. It means that the calcite $\mathrm{C} 5$ is always surrounded by the calcite $\mathrm{C} 4$. In some places, dolomite and aragonite have been identified through SEM observations, suggesting that the fluid was enriched in $\mathrm{Mg}$ at the end of the migration process. Barite and celestite were not identified in the nodules beneath the sub-site A1. However, they are present in nodules closer to sub-sites $\mathrm{B}$ to $\mathrm{H}$ corresponding to the clusters 3 and 4 in the new nomenclature (Gay et al., 2019). They often are in close association with bi-pyramidal quartz in nodules the type of which is called septarium (Guilhaumou et al., 1996) suggesting that the temperature at which they were formed was higher than $90^{\circ} \mathrm{C}$. These quartz often contain hydrocarbon inclusions (Touray and Barlier, 1975) indicating that hydrocarbon migration and quartz precipitation have occurred contemporaneously at burial depths greater than $3000 \mathrm{~m}$ given a standard heatflow of $30^{\circ} \mathrm{C} / \mathrm{km}$ in passive margins (Ranalli and Rybach, 2005). However, the heatflow may have been higher due to the vicinity of salt diapirs (Mello et al., 1995), in particular the diapir of Propiac only $2 \mathrm{~km}$ west of the studied area (See Fig. 1 for location). In the tubes T, few $\mathrm{mm}$ to $\mathrm{cm}$ wide voids are commonly interconnected, defining a very high porosity which is channelized within the conduit. In that case, the calcite $\mathrm{C} 5$ is always identified on the wall of the voids/conduits where it appears more equant.

Hydrocarbons, analyzed as bitumen (Peckmann et al., 1999), are trapped in the porosity between C5 crystals in the tube $\mathrm{T}$, in the nodule $\mathrm{N}$ and in the carbonate lenses of sub sites A1. They are also trapped as inclusions in the calcite $\mathrm{C} 5$ and in quartz within nodules (Guilhaumou et al., 1996; Gay, 2002). However, no hydrocarbons were detected above the sub-site E (see Fig. 2 for location). Regionally, the P-T conditions have been estimated from clay mineral assemblages, vitrinite reflectance determinations (Barlier, 1974) and from aqueous and hydrocarbon-bearing fluid inclusions hosted by quartz crystals in the nodules and septaria (Touray and Barlier, 1975). There is a progressive transition from diagenetic evolution, with temperatures around $150^{\circ} \mathrm{C}$ and pressures lower than $0.2 \mathrm{kbars}$, to low grade metamorphism with temperatures up to $250{ }^{\circ} \mathrm{C}$ and pressures near 0.64 kbars (Gaidon, 1988). The growth of single quartz crystals in the septaria was always synchronous with the thermal culmination. This probably relates to Oligocene sedimentary burial in the west of the basin, and to tectonic overburial caused by Alpine thrust-emplacement in the east (i.e. this study area) which resulted in the generation and the migration of hydrocarbons (Roure et al., 1994).

\subsection{Generations of fluids}

All samples (T-N-A1-R) of calcite $\mathrm{C} 1$ display isotopic $\delta^{13} \mathrm{C}$ and $\delta^{18} \mathrm{O}$ values between $-16 \%$ and $-7 \%$ V-PDB and between $-1 \%$ and $-8 \%$ V-PDB respectively (Fig. 14a), very similar to the isotopic values found in botryoidal aragonite from previous studies (Peckmann et al., 1999; Tribovillard et al., 2013). The $\mathrm{C} 1$ phase, including yellowish calcite $\mathrm{C} 1$ and botryoidal aragonite can be interpreted as bacterial in origin (Roberts et al., 1993) and negative isotopic values are a marker of the microbial mediation in the building of carbonate lenses (Peckmann et al., 1999; Louis-Schmid et al., 2007). The isotopic values of $\mathrm{C} 2$ to $\mathrm{C} 4$ phases are more dispersed with positive $\delta^{13} \mathrm{C}$ and $\delta^{18} \mathrm{O}$ values except for samples N-b and N-c that are closer to the $\mathrm{C} 1$ signature (Fig. 14a). The calcite $\mathrm{C} 5$ in $\mathrm{T}-\mathrm{d}$ and $\mathrm{N}-\mathrm{e}$ samples displays very negative values of $\delta^{13} \mathrm{C}$ between $-24 \%$ and $-19 \%$ V-PDB (Fig. 14a). These values are concordant with isotopic values measured in nodules from previous studies (Peckmann et al., 1999; Louis-Schmid et al., 2007), indicating that fluids that migrated through the tube and nodule had the same signature, probably related to hydrocarbon-bearing phase. However, the isotopic composition taken alone does sign neither the origin of fluids nor their relative occurrence in the history of the palaeo-pockmark.

Seafloor seep carbonates usually form in equilibrium with the $\mathrm{Sr}$ isotope composition of surrounding seawater and pore fluids (Naehr et al., 2000). However, methane seeps pose the potential risk that the seeping fluid carries $\mathrm{Sr}$ with a ${ }^{87} \mathrm{Sr} /{ }^{86} \mathrm{Sr}$ ratio quite different from that of ambient seawater (Paull et al., 1992), which could corrupt the utility of the $\mathrm{Sr}$ isotope signature of the seep carbonate for stratigraphic purposes (Kiel et al., 2014). Deviation from the expected seawater ${ }^{87} \mathrm{Sr} /{ }^{86} \mathrm{Sr}$ value possibly indicates mixing with deep fluids carrying a different isotopic signature, which can be modified during the upward migration by fluid-rock interactions (Teichert et al., 2005; Joseph et al., 2012). Recent studies conducted on Phanerozoic samples have shown that diagenetic alteration, not initial contamination, is the main issue in this approach (Kiel et al., 2014) and new examples of Caribbean fossil seep communities were successfully dated using strontium isotope stratigraphy (Kiel and Hansen, 2015).

In the Beauvoisin area, at least three groups can be identified using their signature on plots of ${ }^{87} \mathrm{Sr} /{ }^{86} \mathrm{Sr}$ versus $\delta^{18} \mathrm{O}$ and versus $\delta^{13} \mathrm{C}$ (Fig. $14 \mathrm{~b}$ and $14 \mathrm{c}$ ). Using the revised version of the Middle-Upper Jurassic strontium isotopic curve (Wierzbowski et al., 2017) as well as LOWESS 5 abacuses from McArthur et al. (2012), several ages were provided for each sample. The fluids expelled at the giant palaeo-pockmark of Beauvoisin hypothetically had a biogenic origin, namely the decomposition of the organic matter contained in the Terres Noires Formation (Gaillard et al., 1996). It is now confirmed by the $\mathrm{Sr}$ isotopic signature of the group $\mathrm{C} 1$. It means that the age of their formation corresponds to the biostratigraphic age of their host formation: Early to Middle Oxfordian for the nodule $\mathrm{N}$ and carbonate lenses in the sub-site A1 and Late Oxfordian for the sub-site R. It also means that they all grew up rapidly into sediments, avoiding any further interaction (and mixing) with later seawater even during shallow burial. This could be due to clay-rich sediments deposited in the Terres Noires Formation avoiding or limiting fluid exchanges. Contrary to hydrothermal sites where the source of fluids 
can be deep (Tran et al., 2014), the methane-rich fluids were originate locally from the host formation, interacting with sulfate coming from seawater through the anaerobic oxidation of methane (AOM). This first generation of fluids can be therefore considered to be biogenic.

The groups $\mathrm{C} 2$ and $\mathrm{C} 3-\mathrm{C} 4$ have very close $\mathrm{Sr}$ isotopic signatures (Fig. 14b and 14c). The group C2 is dated of the Early/Middle Bathonian or Early Tithonian whereas the group C3-C4 shows very similar ages of the Pliensbachian, Middle/ Late Toarcian, Early/Late Bajocian, Late Tithonian, Early/Late Berriasian, Late Aptian or even Late Turonian. Given an average rate of sedimentation of $10 \mathrm{~cm}$ per 1000 years during the Late Oxfordian in the Beauvoisin area (Gay et al., 2019) and a $30 \%$ of compaction for shallow burial, the sub-site A1, nodule $\mathrm{N}$ and tube $\mathrm{T}$ were buried at about $1000 \mathrm{~m}$ below seafloor and the sub-site $\mathrm{R}$ was buried at about $750 \mathrm{~m}$ below seafloor when the Cretaceous started. This means that the Cretaceous seawaters could not interact with the buried features. However, deeper fluids may have provided with a Pliensbachian, Late Toarcian or Bajocian signatures. As shown by the paragenesis and the mineralogical assemblage, the groups $\mathrm{C} 2$ and $\mathrm{C} 3-\mathrm{C} 4$ were created shortly after the brecciation while the carbonate lenses and surrounding marls were still unconsolidated. This means that this episode of fluid migration probably occurred at a relative shallow burial $(<1000 \mathrm{~m})$ with no interactions with the overlying seawaters. Due to their isotopic signatures and the mineralogical continuum from light brown drusy calcite to yellowish equant calcite, the group $\mathrm{C} 2$ has evolved to group $\mathrm{C} 3-\mathrm{C} 4$ during the same event of fluid venting.

The group $\mathrm{C} 5$ has a $\mathrm{Sr}$ isotopic signature of Triassic, Sinemurian or Campanian (Fig. $14 \mathrm{~b}$ and 14c). For similar reasons as for groups $\mathrm{C} 2$ and $\mathrm{C} 3-\mathrm{C} 4$, these samples were deeply buried during the Sinemurian or Campanian, meaning that the fluids may have a signature from Triassic or a mixed signature depending on the levels the fluids had to get through. Paleohydrothermal fluid circulation were initiated during the Lias and potentially occurred until the Bathonian along the Ardèche margin due to salt tectonics of the sedimentary cover over the Triassic salt (Lemoine et al., 1982; Mascle, 1988; Bonijoly et al., 1996; Aquilina et al., 1997; Aquilina and De Dreuzy, 2011). In the Diois and Baronnies geographic areas (including the Beauvoisin area) the main salt diapiric rising is dated of the Mio-Pliocene by means of $\mathrm{K} / \mathrm{Ar}$ techniques (Bellon and Perthuisot, 1980). In the Propiac diapir (see Fig. 1 for location), the $\mathrm{CO}_{2} / \mathrm{N}_{2}$ ratio are the same in the primary inclusions measured in neoformed quartz from the diapiric breccia (Perthuisot and Guilhaumou, 1983) as in the inclusions measured in the quartz redeposited from brownish cap-rock, raft units, or even Triassic material which occur near the top of the diapir (Desmaison et al., 1988). These fluid inclusions were probably formed during a single fluid injection, not necessarily contemporaneous, however, with the thermal culmination of $300{ }^{\circ} \mathrm{C}$ (Edon, 1983; Edon et al., 1991). Fluorescence conducted on fluid inclusions coupled to stable carbon isotope analyses have shown the presence of oil containing n-alkanes generated from thermal maturation of organic matter from the sedimentary pile (Peckmann et al., 1999). The latter is consistent with the total thickness of the Terres Noires Formation which clearly reached a burial depth through the oil window in the lower part and with the Toarcian or Pliensbachian signature of fluids for $\mathrm{C} 3$ and $\mathrm{C} 4$.

\subsection{Evolution of a fluid seep structure}

In marine sediments, methane generated at greater depth and migrating upward interacts with sulfate at the base of the sulfate reduction zone and the top of the methanogenic zone (Martens and Berner, 1974). This sulfate-methane transition zone (SMTZ) is generally found at a depth of about $10 \mathrm{~m}$ below seafloor (t1 in Fig. 15), where the concentrations of sulfate and methane reach their minimum values (Martens and Berner, 1977; Iversen and Jørgensen, 1985; Alperin et al., 1988). Due to an increase in the methane supply from deeper levels during Early Oxfordian, the sulfate is depleted due to anaerobic oxidation of methane (AOM) (Borowski et al., 1999) and the SMI is shifted upward near the center of a pockmark (Gay et al., 2006). At this stage, the byproducts are sulfides in the form of $\mathrm{H}_{2} \mathrm{~S}$ migrating above the SMI and shifting upward the oxic zone ( $\mathrm{t} 2$ in Fig. 15). The center of the pockmark is characterized by reduced sediments and $\mathrm{H}_{2} \mathrm{~S}$ combined with $\mathrm{Fe}$ ions to precipitate framboidal pyrite through bacterial mediation. Pyrite is disseminated in the micritic sediments coming from the hemipelagic sedimentation. Another byproduct of $\mathrm{AOM}$ is $\mathrm{HCO}_{3}{ }^{-}$ions that combined with $\mathrm{Ca}$ of seawater to form aragonite or $\mathrm{Mg}$-rich calcite around nucleus such as sponge spicules or lithic fragments in growing nodules (Gaillard et al., 1992; Gay, 2002; Gay et al., 2019).

As the flux of methane is increasing, the SMTZ is shifted upward until the fluid can be expelled directly at the seabed ( $\mathrm{t} 3$ in Fig. 15). In that case, methane seepage results in carbonate precipitation forming lenses or pavements encased in surrounding limestones or marlstones as shown in many fossil (Campbell and Bottjer, 1995b; Campbell et al., 2002; Kiel and Little, 2006; Kiel, 2010; Vrijenhoeck, 2013) and modern (Campbell, 2006; Amano et al., 2010; Teichert and van de Schootbrugge, 2013) basins worldwide. Sedimentary facies at the bottom are concentrically arranged, with methanedependent features in the center of the pockmark and sulfidedependent features at the periphery of the depression as shown in the modern Regab giant pockmark in the Lower Congo Basin (Gay et al., 2006).

It was shown that carbonate pavements formed in situ and grew up downward into the sediments (Bayon et al., 2009). It means that all porosity will be clogged by a microsparitic calcitic cement $\mathrm{C} 1$ forming the carbonate lens. This is also the case beneath the sub-site where the feeding conduits are progressively clogged forming tubes. The fluids are then trapped beneath the carbonate lens playing the role of a permeability barrier, as shown in modern seep sites (Bayon et al., 2009), and the fluids migrated laterally in any direction forming a new carbonate lens at the seafloor. As shown for the sub-site E1 (Fig. 4b), a sub-site is formed by compensation of the carbonate lenses due to the lateral shift of the fluid seep point (t4 and t5 in Fig. 15). All stacked carbonate lenses and their associated nodules formed in a general $120 \mathrm{~m}$ wide depression of about 4 to $6 \mathrm{~m}$ compared to the surrounding seafloor (Gay et al., 2019), and probably 5 to $8 \mathrm{~m}$ given a compaction rate of $30 \%$. 


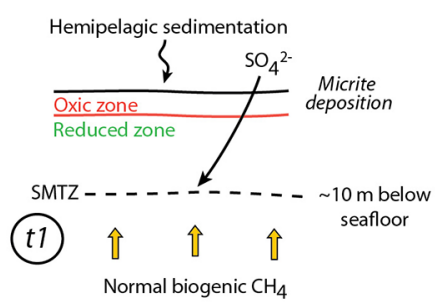

No SEEP
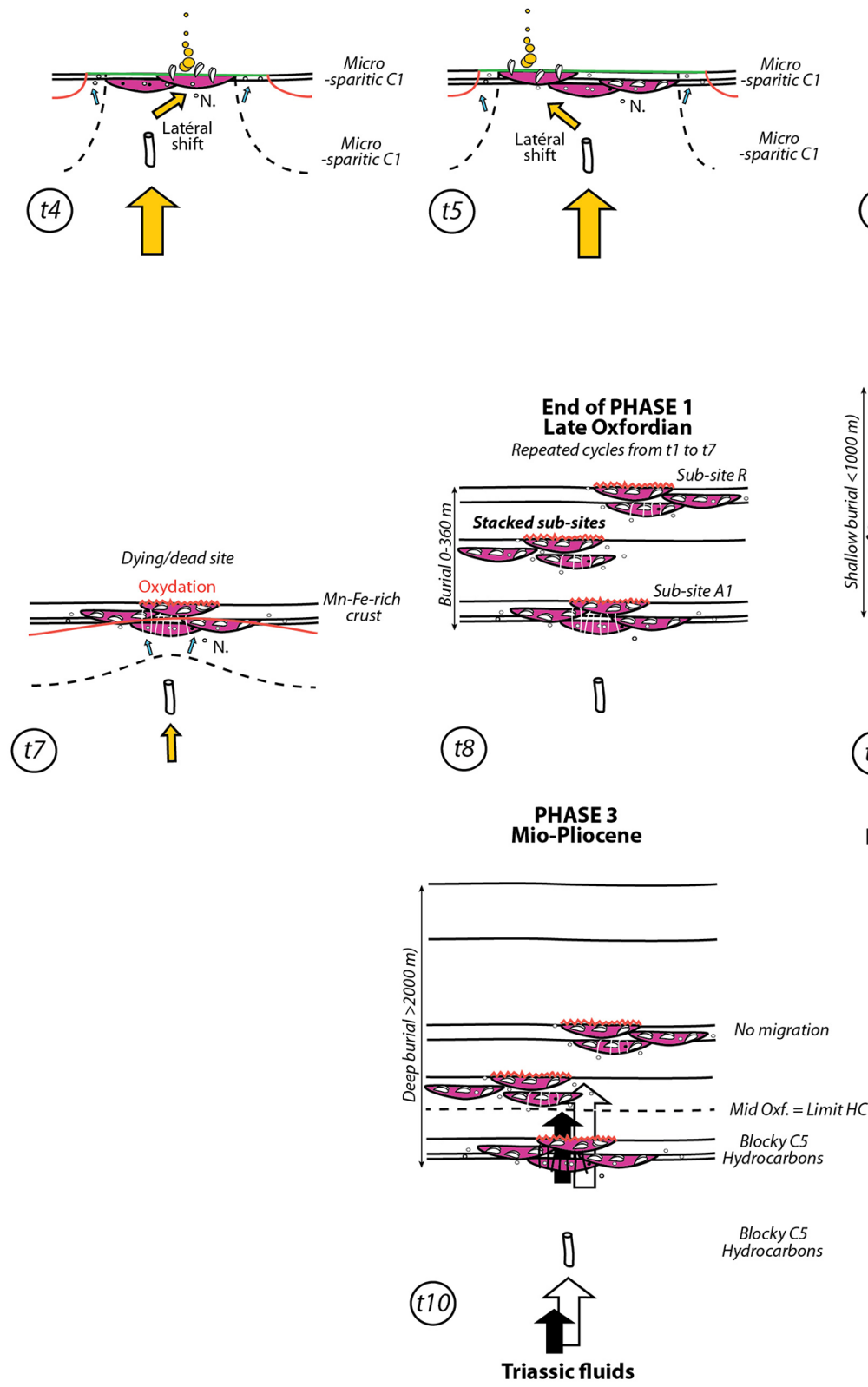

(t8)

Start of PHASE 1 Early Oxfordian

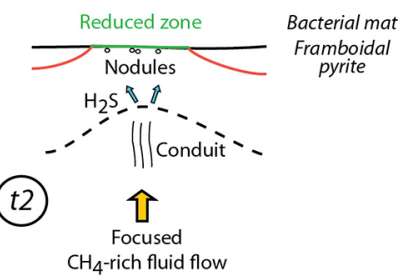

Early Bathonian

to Early Oxfordian fluids

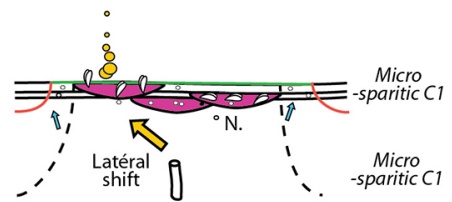

(t5)<smiles>C1=CCC1</smiles>

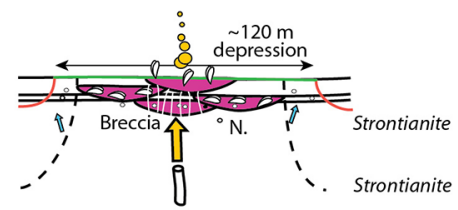

(t6)

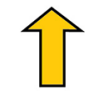

(t3)

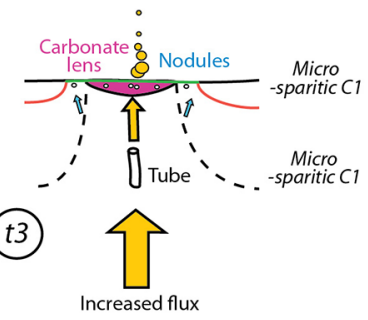

Cretaceous

Seafloor seep?
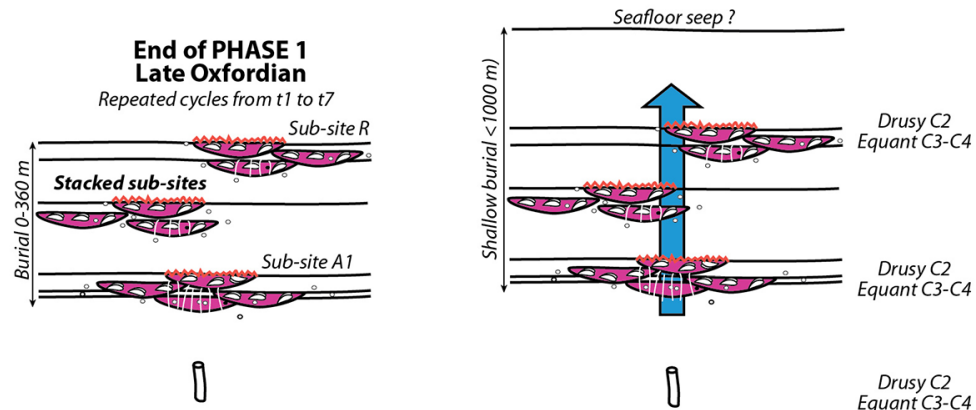

(t9) Drusy C2
Equant C3-C4

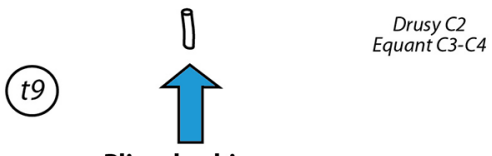

Pliensbachian, Late Toarcian, Bajocian fluids

Fig. 15. Model of formation of a pockmark integrating three main phases of fluid migration. The first phase started on Early Oxfordian, remobilizing biogenic fluids from the local host formations, and ended on Late Oxfordian with sub-site R. The second phase corresponds to a fluid migration coming from Pliensbachian, Late Toarcian and Bajocian levels that occurred during Cretaceous (probably Early Cretaceous). The last phase is related to bitumen-bearing fluids that were expelled along faults during the regional salt diapir rising dated of Mio-Pliocene in the SE basin of France. 
Once a significant number of carbonate lenses had been formed, the fluids accumulated beneath the sub-site increasing the pore fluid pressure and the unconsolidated basal lenses were brecciated by hydraulic fracturing, allowing the fluids to be expelled at the seabed. The clasts in the breccia often host strontianite, which is always crystalized in contact with the micritic matrix of the clasts and the calcite $\mathrm{C} 1$ in shell fragments (t6 in Fig. 15).

At sites where AOM is active, methane concentration varies strongly depending on spatial and temporal availability of methane supply and microbial turnover rates (Knittel and Boetius, 2009; Deusner et al., 2014). Sulfate depletion is driven by methane oxidation in sediment pore-waters through bacterially-mediated reactions, inducing a change in redox conditions (Feng and Roberts, 2011) and favoring carbonate precipitation (Bayon et al., 2007; Ge et al., 2010; Vanneste et al., 2012, and references therein). However, once the focused biogenic fluid flow was reduced at depth, or because of the lateral shift of the fluid seeps during a period of relative quiescence (Gay et al., 2019), methane supply did not sustain the AOM at the seabed and both the SMTZ and the oxic zone were shifted downward, leading to the formation of an oxidized Mn-Fe-rich crust on top of the last (i.e., youngest and not buried yet) carbonate lens of a sub-site ( $\mathrm{t} 7$ in Fig. 15), as previously shown for sub-sites F and G in the area (Gay et al., 2019). Finally the giant pockmark of Beauvoisin is the result of repeated cycles of fluid expulsion from $t 1$ to 77 leading to the 19 stacked sub-sites A to T until Late Oxfordian (t8 in Fig. 15).

Based on the $\mathrm{C}$ and $\mathrm{O}$ isotopic signatures it was shown that a second phase of fluid flow came from long-lasting fluids that became more in equilibrium with surrounding marls. It is evidenced by continuous growing of crystals from light-brown drusy calcite $\mathrm{C} 2$ to yellowish microsparitic to equant calcites $\mathrm{C} 3$ and $\mathrm{C} 4$. The Sr ratios show that the fluid that induced the precipitation of the calcite $\mathrm{C} 2$ has a $\mathrm{Sr}$ isotope composition identical to Pliensbachian or Late Toarcian seawater. The fluids then migrated through pre-existing pipes, conduits and fractures ( $t 9$ in Fig. 15). However, no other fossil seep sites were identified in the surrounding Cretaceous intervals in the Beauvoisin area. So, the fluids may have been trapped leading to slow processes of crystallization for $\mathrm{C} 2$ and $\mathrm{C} 3-\mathrm{C} 4$.

A third phase of bitumen-rich fluids was identified in the Beauvoisin palaeo-pockmark (t10 in Fig. 15). It is probably related to deep fluids derived from the same Pliensbachian and/ or Toarcian source rocks that have reached the oil window and the produced fluids have migrated through fault systems developed around the Triassic salt diapir of Propiac, which is located only $2 \mathrm{~km}$ westward. This has implications for fluid remobilization during burial as shown in the Adriatic foreland basin where salt withdrawal may be the main cause for oil migration (Ladanza et al., 2015).

\section{Conclusion}

Previous studies conducted in the Beauvoisin area showed that all sub-sites $A$ to $R$ developed in a $800 \mathrm{~m}$ wide depression for over 3.4 Ma, meaning that it can now be considered to be a giant fossil pockmark (Gay et al., 2019 and references therein). However, the origin of fluids remained unclear since the first identification of the Beauvoisin seep site in the 1980s (Gaillard et al., 1985). The detailed petrographic analyses of all mineralogical phases identified in a tube, in nodules and in the sub-sites A1, E1 and R have led to the conclusion that the evolution of a seep site is entirely recorded from its birth to its death and long after its burial:

- the increase of methane-rich fluids flow to the seafloor leads to an upward shift of diagenetic horizons, such as the sulfate-methane interface and the oxic zone, allowing carbonate precipitation at the seafloor through AOM;

- a carbonate lens probably represents a permeability barrier and fluids have to laterally shift to find a new seep pathway, forming a new carbonate lens by compensation. A sub-site is composed of all compensated carbonate lenses. If the fluids are trapped beneath a sub-site, the pore-fluid pressure increases and leads to hydraulic fractures in the basal lenses;

- once the focused fluid flow is reduced, the diagenetic horizons are shifted downward to their common position below the seafloor and the upper carbonate lens is oxidized, marking the end of a sub-site before its burial;

- even if a seep site is buried, the conduits, pipe and fractures remain open in unconsolidated and shallow buried sediments, allowing a new phase of deeper fluids to be precipitated. In that case, the mineralogy shows that it is a long-lasting process and there is no evidence that they reached the seafloor. A last phase of bitumen-rich fluids can be recorded in the conduits, meaning that a source rock has reached the oil window at depth and followed the same pathway at the expulsion stage.

The study of the giant fossil pockmark of Beauvoisin shows that several episodes of fluid migration have led to its formation. However, most of the precipitated mass of carbonates was created early, when it was active and cropping out at the seafloor. The other phases remained relict and one (or more) fluid phase may have been missed (not recorded). Some results suggest that the salt tectonic activity may have caused the late two fluid migrations in the area, one coming from the Late Toarcian and/or Bajocian levels during early Cretaceous, one coming from the Triassic evaporites, such as the Propiac diapir, during Mio-Pliocene. It shows that fluid migration in fossil cold seeps can be used as a marker of the regional geodynamic activity of the SE basin of France.

Acknowledgements. The authors would like to thank all Masters students involved in this project by order: Elie Boidin, Yolaine Rubert, Morgane Bizeray, Alexandra Gueguen, Amandine Castillo, Charly Poitevin, Stanislas Delivet, Maëva Evesque, Laure Matiakh, Aloïse Chabbert-Gondart and Audrey Laplanche. The authors acknowledge all colleagues who participated in discussion in the field and greatly improved our understanding of the area. They also thank Action Marges (INSU) that supported the project for many years since 2009 .

\section{References}

Agirrezabala LM, Kiel S, Blumenberg M, Schäfer N, Reitner J. 2013. Outcrop analogues of pockmarks and associated methane-seep carbonates: a case study from the Lower Cretaceous (Albian) of the 
Basque-Cantabrian Basin, western Pyrenees. Palaeogeography, Palaeoclimatology, Palaeoecology 390: 94-115.

Aharon P. 2000. Microbial processes and products fueled by hydrocarbons at submarine seeps. In: Riding RE, Awramik SM, eds. Microbial sediments. Berlin: Springer-Verlag, pp. 270-281.

Alperin ML, Reeburgh WS, Whiticar MJ. 1988. Carbon and hydrogen isotope fractionation resulting from anaerobic methane oxidation. Global Biogeochemical Cycles 2: 279-288

Aquilina L, Sureau JF, Steinberg M, GPF team. 1997. Comparison of surface, aquifer, and pore waters form a Mesozoïc sedimentary basin and its underlying Paleozoïc basement, Southeastern France. Chemical evolution of waters with diagenesis and relationship between aquifers. Chemical Geology 138: 185-209.

Aquilina L, De Dreuzy J-R. 2011. Relationship of present saline fluid with paleomigration of basinal brines at the basement/sediment interface (Southeast basin - France). Applied Geochemistry 26: 1933-1945.

Artru P. 1972. Les terres noires du bassin rhodanien (Bajocien supérieur à Oxfordien moyen) : stratigraphie, sédimentologie, géochimie - Alpes françaises. Ph.D. Thesis. Lyon, France: Claude Bernard University, 173 p.

Aloisi G, Bouloubassi I, Heijs SK, Pancost RD, Pierre C, Damste JSS, et al. 2002. CH4-consuming microorganisms and the formation of carbonate crusts at cold seeps. Earth and Planetary Science Letters 203(1): 195-203.

Aloisi G, Pierre C, Rouchy JM, Foucher JP, Woodside J. 2000. Methanerelated authigenic carbonates of eastern Mediterranean Sea mud volcanoes and their possible relation to gas hydrate destabilisation. Earth and Planetary Science Letters 184(1): 321-338.

Amano K, Jenkins RG, Aikawa M, Nobuhara T. 2010. A Miocene chemosynthetic community from the Ogaya Formation in Joetsu: evidence for depth-related ecologic control among fossil seep communities in the Japan Sea back-arc basin. Palaeogeography, Palaeoclimatology, Palaeoecology 286: 164-170.

Barbieri R, Cavalazzi B. 2005. Microbial fabrics from Neogene cold seep carbonates, Northern Apennine, Italy. Palaeogeography, Palaeoclimatology, Palaeoecology 227: 143-155.

Barlier J. 1974. Recherches paléothermométriques dans le domaine des Terres Noires subalpines méridionales. Thèse $3^{\mathrm{e}}$ cycle. Orléans, $98 \mathrm{p}$.

Bayon G, Henderson GM, Bohn M. 2009. U-Th stratigraphy of a cold seep carbonate crust. Chemical Geology 260: 47-56.

Bayon G, Pierre C, Etoubleau J, Voisset M, Cauquil E, Marsset T, et al. 2007. $\mathrm{Sr} / \mathrm{Ca}$ and $\mathrm{Mg} / \mathrm{Ca}$ ratios in Niger Delta sediments: implications for authigenic carbonate genesis in cold seep environments. Marine Geology 241: 93-109.

Bellon H, Perthuisot V. 1980. Âges radiométriques K-Ar de feldspaths potassiques du Trias évaporitique vocontien. $C R \mathrm{Acad}$ Sci Paris 290: 1241-1244.

Bréheret JG. 1994. Faisceaux de bancs calcaires noduleux dans I'Apto-albien du bassin Vocontien: I'expression diagénétique d'une sédimentation saccadée. $C R$ Acad Sci Paris 318: 513-519.

Bohrmann G, Greinert J, Suess E, Torres M. 1998. Authigenic carbonates from the Cascadia subduction zone and their relation to gas hydrate stability. Geology 26(7): 647-650.

Bonijoly D, Perrin J, Roure F, Bergerat F, Courel L, Elmi S, et al. 1996. The Ardèche palaeomargin on the South-East Basin of France. Mesozoic evolution of a part of the Tethyan continental margin (Géologie Profonde de la France programme). Marine and Petroleum Geology 13: 607-624.

Borowski WS, Paull CK, Ussler B. 1999. Global and local variations of interstitial sulfate gradients in deep-water, continental margin sediments: sensivity to underlying methane and gas hydrates. Marine Geology 159: 131-154.

Bourseau JP. 1977. L'Oxfordien moyen à nodules des « Terres Noires » de Beauvoisin (Drôme). Nouv. Arch. Mus. Hist. Nat. Lyon 15: 116 p.

Caillaud A. 2018. Dépôts organiques en milieu marin: les facteurs clés des bassins hémipélagiques. Le Mésozoïque du bassin du SudEst de la France. PhD Thesis. Université de Lille, 354 p.

Campbell KA. 2006. Hydrocarbon seep and hydrothermal vent paleoenvironments and paleontology: past developments and future research directions. Palaeogeography, Palaeoclimatology, Palaeoecology 232: 362-407.

Campbell KA, Farmer JD, Des Marais D. 2002. Ancient hydrocarbon seeps from the Mesozoic convergent margin of California: carbonate geochemistry, fluids and palaeoenvironments. Geofluids 2: 63-94.

Campbell KA, Bottjer DJ. 1995a. Brachiopods and chemosymbiotic bivalves in Phanerozoic hydrothermal vent and cold seep environments. Geology 23: 321-324.

Campbell KA, Bottjer DJ. 1995b. Peregrinella: an Early Cretaceous cold-seep-restricted brachiopod. Paleobiology 24: 461-478.

Cangemi M, Di Leonardo R, Bellanca A, Cundy A, Neri R, Angelone M. 2010. Geochemistry and mineralogy of sediments and authigenic carbonates from the Malta Plateau, Strait of Sicily (Central Mediterranean): relationships with mud/fluid release from a mud volcano system. Chemical Geology 276: 294-308.

Cavagna S, Clari P, Martire L. 1999. The role of bacteria in the formation of cold seep carbonates: geological evidence from Monferrato (Tertiary NW Italy). Sedimentary Geology 126: 253-270.

Clari P, Martire L. 2000. Cold seep carbonates in the tertiary of northwest Italy: evidence of bacterial degradation of methane. In: Riding RE, Awramik SM, eds. Microbial Sediments. Berlin: Springer-Verlag, pp. 261-269.

Clari P, Fornara L, Ricci B, Zuppi GM. 1994. Methane-derived carbonates and chemosymbiotic communities of Piedmont (Miocene, northern Italy): an update. Geo-Marine Letters 14: 201-209.

Claypool GE, Holser WT, Kaplan IR, Sakai H, Zak I. 1980. The age curves of sulphur and oxygen isotopes in marine sulphate and their interpretation. Chemical Geology (Isotope geoscience section) 28: 199-260.

Craig H, Gordon I. 1965. Deuterium and oxygen-18 variations in the ocean and marine atmosphere. In: Tongiorgi E, ed. Stable Isotopes in Oceanographic Studies and Paleotemeratures. Pisa, Italy: Consiglio Nazionale delle Richerche, Laboratorio di Geologia Nucleare, pp. 9-130.

Dardeau G. 1988. Tethyan evolution and Alpine reactivation of Jurassic extensional structures in the French "Alpes Maritimes". Bulletin de la Société Géologique de France 8(4): 651-657.

Debrand-Passard S. 1984. Grandes lignes et principales étapes de l'évolution géodynamique du Sud-Est de la France. In: DebrandPassard S, et al., eds. Synthèse géologique du Sud-Est de la France. Mém. BRGM, 125: 581-599.

Desmaison YL, Nicot E, Guilhaumou N. 1988. Le materiel triassique inseré dans les Terres Noires: arguments petrographiques pour une halocinèse précoce dans la région de Buis-les-Baronnies. Bull Soc Geol Fr IV: 759-770.

Deusner C, Holler T, Arnold GL, Bernasconi SM, Formolo MJ, Brunner B. 2014. Sulfur and oxygen isotope fractionation during sulfate reduction coupled to anaerobic oxidation of methane is dependent on methane concentration. Earth and Planetary Science Letters 399: 61-73.

Edon M, Guilhaumou N, Perthuisot V, Laval M. 1991. Diapirism and hydrothermalism from Diois and Baronnies (SE, France). PLINIUS. Supplemente italiano all'Europeen Journal of Mineral 5: 70-71. 
Edon M. 1983. Contribution à la caracterisation P-T-t-X des fluides et des neoformations minérales dans le Trias en place ou diapirique et dans sa couverture sédimentaire dans le bassin sud est (France). Thèse. Université d'Orléans, $241 \mathrm{p}$.

Feng D, Roberts HH. 2011. Geochemical characteristics of the barite deposits at cold seeps from the northern Gulf of Mexico continental slope. Earth and Planetary Science Letters 309: 89-99.

Feng D, Chen D, Peckmann J, Bohrmann G. 2010. Authigenic carbonates from methane seeps of the northern Congo fan: microbial formation mechanism. Marine and Petroleum Geology 27(4): 748-756.

Gaidon J-L. 1988. Minéralisations et structuration d'une marge continentale passive: l'exemple des concrétions tubulaires du barssin subalpin (Callovien-Oxfordien). Thèse de doctorat. Lyon: Université Claude Bernard-Lyon 1, 222 p.

Gaillard C, Neraudeau D, Thierry J. 2011. Tithonia oxfordiana, a new irregular echinoid associated with Jurassic seep deposits in SouthEast France. Palaeontology 54: 735-752.

Gaillard C, Atrops F, Marchand D, Hanzo M, Lathuilière B, Bodeur Y, et al. 1996. Description stratigraphique préliminaire des faisceaux alternants de l'Oxfordien moyen dans le bassin dauphinois (SudEst de la France). Géologie de la France 1: 17-24.

Gaillard C, Rio M, Rolin Y, Roux M. 1992. Fossil chemosynthetic communities related to vents or seeps in sedimentary basins: the pseudobioherms of southeastern France compared to other world examples. Palaios 7: 451-465.

Gaillard C, Rolin Y. 1988. Relation entre tectonique synsédimentaire et pseudobiohermes (Oxfordien de Beauvoisin-Drôme-France). Un argument supplémentaire pour interpréter les pseudobiohermes comme formés au droit de sources sous-marines. Comptes Rendus de l'Académie des Sciences Paris 307: 1265-1270.

Gaillard C, Bourseau J-P., Boudeulle M, Pailleret P, Rio M, Roux M. 1985. Les pseudobiohermes de Beauvoisin (Drôme) : un site hydrothermal sur la marge téthysienne à l'Oxfordien? Bulletin de la Société Géologique de France 1: 69-78.

Gay A, Lopez M, Potdevin J-L, Vidal V, Varas G, Favier A, et al. 2019. 3D morphology and timing of the giant fossil pockmark of Beauvoisin, SE Basin of France. Journal of the Geological Society of Londons 176(1): 61-77.

Gay A, Lopez M, Berndt C, Séranne M. 2007. Geological controls on focused fluid flow associated with seafloor seeps in the Lower Congo Basin. Marine Geology 244: 68-92.

Gay A, Lopez M, Ondreas H, Charlou J-L., Sermondadaz G, Cochonat P. 2006. Seafloor facies related to upward methane flux within a Giant Pockmark of the Lower Congo Basin. Marine Geology 226: 81-95.

Gay A. 2002. Les marqueurs géologiques de la migration et de l'expulsion des fluides sédimentaires sur le plancher des marges passives matures. Exemples dans le Bassin du Congo. Thèse. Université de Lille 1, $426 \mathrm{p}$.

Ge L, Jiang S-Y, Swennen R, Yang T, Yang J-H, Wu N-Y, Liu J, Chen DH. 2010. Chemical environment of cold seep carbonate formation on the northern continental slope of South China Sea: Evidence from trace and rare earth element geochemistry. Marine Geology 277: $21-30$

Ge L, Jiang S-Y. 2013. Sr isotopic compositions of cold seep carbonates from the South China Sea and the Panoche Hills (California, USA) and their significance in palaeooceanography. Journal of Asian Earth Sciences 65: 34-41.

Gradstein JG. 2012. “The Geologic Time Scale 2012” by J.G. Ogg, M.D. Schmitz and G.M. Ogg. Elsevier.

Guilhaumou N, Touray JC, Perthuisot V, Roure F. 1996. Palaeocirculation in the basin of southeastern France sub-alpine range: a synthesis from fluid inclusions studies. Marine and Petroleum Geology 13(6): 695-706.

Haas A, Peckmann J, Elvert M, Sahling H, Bohrmann G. 2010. Patterns of carbonate authigenesis at the Kouilou pockmarks on the Congo deep-sea fan. Marine Geology 268(1):129-136.

Himmler T, Birgel D, Bayon G, Pape T, Ge L, Bohrmann G, Peckmann J. 2015. Formation of seep carbonates along the Makran convergent margin, northern Arabian Sea and a molecular and isotopic approach to constrain the carbon isotopic composition of parent methane. Chemical Geology 415: 102-117.

Iversen N, Jørgensen BB. 1985. Anaerobic methaneoxidation rates at the sulfate methane transition in marine-sediments from Kattegat and Skagerrak (Denmark). Limnologyand Oceanography 30(5): 944-955.

Joseph C, Torres ME, Martin RA, Haley BA, Pohlman JW, Riedel M, Rose K. 2012. Using the $87 \mathrm{Sr} / 86 \mathrm{Sr}$ of modern and paleoseep carbonates from the northern Cascadia to link modern fluid flow to the past. Chemical Geology 334: 122-130.

Kiel S, Hansen BT. 2015. Cenozoic methane-seep faunas of the Caribbean region. PLoS One 10(10): e0140788.

Kiel S, Hansen C, Nitzsche KN, Hansen BT. 2014. Using 87Sr/86Srratios to date fossil methane seep deposits: methodological requirements and an example from the Great Valley Group California. Journal of Geology 122: 353-366.

Kiel S. 2013. Lucind bivalves from ancient methane seeps. Journal of Molluscan Studies 79: 346-363. https://doi.org/10.1093/mollus/ eyt035.

Kiel S. 2010. The fossil record of vent and seep mollusks. In: Kiel S, ed. The Vent and seep biota: aspects from microbes to ecosystems. Heidelberg: Springer. Topics in Geobiology 33: 255-278.

Kiel S, Little CTS. 2006. Cold seep mollusks are older than the general marine mollusk fauna. Science 313: 1429-1431.

Knittel K, Boetius A. 2009. Anaerobic oxidation of methane: progress with an unknown process. Annual Review of Microbiology 63: 311344.

Ladanza A, Sampalmieri G, Cipollari P. 2015. Deep-seated hydrocarbons in the seep "Brecciated Limestones" of the Maiella area (Adriatic foreland basin): evaporitic sealing and oil re-mobilization effects linked to the drawdown of the Messinian Salinity Crisis. Marine and Petroleum Geology 66: 177-191.

Ladanza A, Sampalmieri G, Cipollari P, Mola M, Cosentino D. 2013. The "Brecciated Limestones" of Maiella, Italy: rheological implications of hydrocarbon-charged fluid migration in the Messinian Mediterranean Basin. Palaeogeography, Palaeoclimatology, Palaeoecology 390: 130-147.

Lemoine M. 1985. Structuration jurassique des Alpes occidentales et palinspatique de la Téthys ligure. Bulletin de la Société Géologique de France I(1): 126-137. https://doi.org/10.2113/ gssgfbull.I.1.127.

Lemoine M, Arnaud-Vanneau A, Arnaud H, Létolle R, Mével C, Thieuloy JP. 1982. Indices possibles de paléo-hydrothermalisme marin dans le Jurassique et le Crétacé des Alpes occidentales (océan téthysien et sa marge continentale européenne): essai d'inventaire. Bulletin de la Société Géologique de France S7XXIV(3): 641-647. https://doi.org/10.2113/gssgfbull.S7XXIV.3.641.

Louis-Schmid B, Rais P, Logvinovich D, Bernasconi SM, Weissert H. 2007. Impact of methane seeps on the local carbon-isotope record: a case study from a Late Jurassic hemipelagic section. Terra Nova 19(4): 259-265.

Martens CS, Berner RA. 1977. Interstitial water chemistry of anoxic Long Island Sound sediments. I. Dissolved gases. Limnology and Oceanography 22: 10-25. 
Martens CS, Berner RA. 1974. Methane production in interstitial waters of sulfate-depleted marine sediments. Science 185(4157): $1167-1169$.

Mascle G, et al. 1988. Salt tectonics, Tethyan rifting and Alpine folding in the French Alps. Bulletin de la Société Géologique de France 8(4): 747-758.

McArthur JM, Howarth RJ, Shields GA. 2012. Strontium isotope stratigraphy. In: Gradstein FM, Ogg JG, Schmitz M, Ogg G, eds. The Geologic Time Scale. Elsevier, pp. 127-144.

Mello UT, Karner GD, Anderson RN. 1995. Role of salt in restraining the maturation of subsalt source rocks. Marine and Petroleum Geology 12(7): 697-716.

Naehr TH, Rodriguez NM, Bohrmann G, Paull CK, Botz R. 2000. Methane-derived authigenic carbonates associated with gas hydrate decomposition and fluid venting above the Blake Ridge Diapir. In: Paull CK, Matsumoto R, Wallace PJ, Dillon WP, eds. Proceedings of the Ocean Drilling Program, Scientific Results, College Station, TX: ODP, 164, pp. 1-16. https://doi.org/10.2973/ odp.proc.sr.164.228.2000.

Paull CK, Chanton JP, Neumann AC, Coston JA, Martens CS. 1992. Indicators of methane-derived carbonates and chemosynthetic organic carbon deposits: examples from the Florida escarpment. In: Beauchamp B, Von Bitter P, eds. Chemosynthesis: Geological Processes and Products. - Soc. Econ. Paleontol. Mineral, pp. 361-375.

Peckmann J, Reimer A, Luth U, Luth C, Hansen BT, Heinicke C, et al. 2001. Methane-derived carbonates and authigenic pyrite from the northwestern Black Sea. Mar Geol 177:129-50.

Peckmann J, Thiel V, Michaelis W, Clari P, Gaillard C, Martire L, Reitner J. 1999. Cold seep deposits of Beauvoisin (Oxfordian; southeastern France) and Marmorito (Miocene; northern Italy): microbially induced authigenic carbonates. International Journal of Earth Sciences 88: 60-75.

Pellenard P, Deconinck JF, Huff WD, Thierry J, Marchand D, Trouiller A. 2003. Characterisation and correlation of Upper Jurassic (Oxfordian) bentonite deposits of the Paris Basin and the South-Eastern Basin of France. Sedimentology 50(6): 1035-1060.

Perthuisot V, Guilhaumou N. 1983. Les diapirs triasiques du domaine vocontien: phases diapiriques et hydrothermales en domaine périalpin. Bull. Soc. Geol Fr. XXV: 397-410

Pin C, Briot D, Bassin C, Poitrasson F. 1994. Concomitant separation of strontium and samarium-neodymium for isotopic analysis in silicate samples, based on specific extraction chromatography. Analytica Chimica Acta 298(2): 209-217.

Ranalli G, Rybach L. 2005. Heat flow, heat transfer and lithosphere rheology in geothermal areas: features and examples. Journal of Volcanology and Geothermal Research 148: 3-19.

Richard P, Shimizu N, Allegre CJ. 1976. ${ }^{143} \mathrm{Nd} /{ }^{146} \mathrm{Nd}$, a natural tracer: an application to oceanic basalts. Earth Planet. Sci. Lett. 31:269-278.

Roberts HH, Aharon P, Walsh MM. 1993. Cold-seep carbonates of the Louisiana continental slope-to-basin floor. In: Rezak R, Lavoie DL, eds. Carbonate microfabrics. Springer-Verlagp, p. 95-104.
Rolin Y, Gaillard C, Roux M. 1990. Écologie des pseudobiohermes des Terres Noires jurassiques liés à des paléo-sources sousmarines. Le site oxfordien de Beauvoisin (Drôme, Bassin du SudEst, France). Paleogeography, Palaeoclimatology, Palaeoecology 80: 79-105.

Rolin Y. 1987. Gisements fossilifères liés à des sources sousmarines dans le bassin des Terres Noires : le site oxfordien de Beauvoisin (Drôme, Chaînes subalpines méridionales), comparaison avec les sites océaniques actuels. Thèse de doctorat. Lyon, $128 \mathrm{p}$.

Roure F, Brun JP, Colletta B, Vially R. 1994. Multiphase extensional structures, fault reactivation and petroleum plays in the alpine foreland basin of southeastern France. In: Mascle A, ed. Hydrocarbon and Petroleum Geology of France, Special publication. New York: Springer Verlag, pp. 245-248.

Senowbari-Daryan B, Gaillard C, Peckmann J. 2007. Crustacean microprolites from Jurassic (Oxfordian) hydrocarbon-seep deposits of Beauvoisin, southeastern France. Facies 53: 229-238.

Teichert BMA, van de Schootbrugge B, eds. 2013. Tracing Phanerozoic hydrocarbon seepage from local basins to the global Earth system. Elsevier. https://doi.org/10.1016/j.palaeo.2013.10.001.

Teichert BMA, Bohrmann G, Suess E. 2005. Chemoherms on Hydrate Ridge - Unique microbially-mediated carbonate build-ups growing into the water column. Palaeogeography, Palaeoclimatology, Palaeoecology 227: 67-85.

Touray JC, Barlier L. 1975. Liquid and gaseous hydrocarbon inclusions in quartz monocrystals from Terres noires and 'Flysch a helminthoides' (French Alps). Fortschr Mineral 52: 419-426.

Tran TH, Kato K, Wada H, Fujioka K, Matsuzaki H. 2014. Processes involved in calcite and aragonite precipitation during carbonate chimney formation on Conical Seamount, Mariana Forearc: evidence from geochemistry and carbon, oxygen, and strontium isotopes. Journal of Geochemical Exploration 137: 55-64.

Tribovillard N, Armynot du Châtelet E, Gay A, Barbecot F, Sansjofre P, Potdevin J-L. 2013. Geochemistry of cold seepage-impacted sediments: per-ascensum or per-descensum trace metal enrichment? Chemical Geology 340: 1-12.

Tribovillard N-P., Cotillon P, Espitalié J. 1987. Relation entre venues salines par tectonique salifère et sédimentation, mise en évidence par l'étude de la matière organique. Le cas des Terres Noires jurassiques du bassin dauphinois (SE de la France). C. R. Acad. Sci., Paris 305(II): 23-26.

Vanneste H, Kastner M, James RH, Connelly DG, Fisher RE, Kelly-Gerreyn BA, et al. 2012. Authigenic carbonates from the Darwin Mud Volcano, Gulf of Cadiz: a record of palaeo-seepage of hydrocarbon bearing fluids. Chemical Geology 300-301: 24-39.

Vrijenhoeck RC. 2013. On the instability and evolutionary age of deep-sea chemosynthetic communities. Deep-Sea Research II 92: 189-200.

Wierzbowski H, Anczkiewicz R, Pawlak J, Rogov MA, Kuznetsov AB. 2017. Revised Middle-Upper Jurassic strontium isotope stratigraphy. Chemical Geology 466: 239-255.

Cite this article as: Gay A, Favier A, Potdevin J-L, Lopez M, Bosch D, Tribovillard N, Ventalon S, Cavailhes T, Neumaier M, Revillon S, Travé A, Bruguier O, Delmas D, Nevado C. 2020. Poly-phased fluid flow in the giant fossil pockmark of Beauvoisin, SE basin of France, BSGF - Earth Sciences Bulletin 191: 35. 